\title{
Working
}

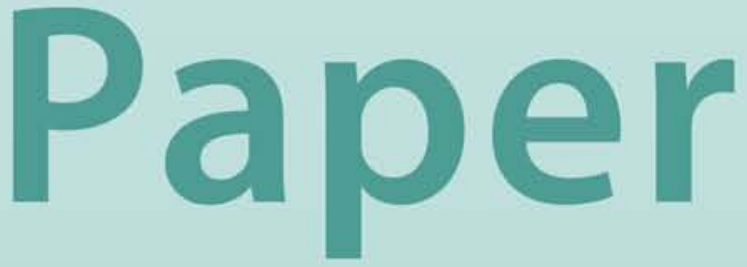


Liberalized Markets Have More Stable Exchange Rates: Short-Run Evidence from Four Transition Countries

\author{
Aleš Bulír
}




\title{
IMF Working Paper
}

Policy Development and Review Department

\section{Liberalized Markets Have More Stable Exchange Rates: Short-Run Evidence from Four Transition Countries}

\author{
Prepared by Aleš Bulír ${ }^{1}$ \\ Authorized for distribution by Timothy Lane
}

February 2004

\begin{abstract}
This Working Paper should not be reported as representing the views of the IMF. The views expressed in this Working Paper are those of the author(s) and do not necessarily represent those of the IMF or IMF policy. Working Papers describe research in progress by the author(s) and are published to elicit comments and to further debate.

The paper looks at the hypothesis that financial market liberalization can create a basis for more stable exchange rates, as deviations of exchange rates from equilibrium levels bring forth stabilizing flows of liquidity. This hypothesis suggests that opening financial markets militates in favor of exchange rate flexibility by increasing the viability of a floating regime, as well as making it more difficult to maintain a peg. The paper examines this hypothesis in a sample of four transition economies and finds that exchange rates tend to return faster to their Hodrick-Prescott-based values where markets are liberalized. The results suggest that early and successful foreign exchange liberalization pays off in terms of depth of the market and, hence, faster adjustment of exchange rate to shocks. Moreover, it implies that central banks should not be overly concerned with short-run volatility of their national exchange rates.
\end{abstract}

JEL Classification Numbers: F31, F33, C32

Keywords: Exchange rate, endogenous liquidity, error-correction mechanism, nonlinearity Author’s E-Mail Address: abulir@imf.org

\footnotetext{
${ }^{1}$ This work was undertaken while the author was on sabbatical leave at the Research Department of the Czech National Bank. The paper benefited from comments by Josef Arlt, Bergljot Barkbu, Alexis Derviz, Bob Flood, Tomáš Holub, Miroslav Hrnčíř, Kornélia Krajnyák, Tomáš Kvapil, Tim Lane, Leslie Lipschitz, Martin Mandel, Alex Mourmouras, Katka Šmídková, István Szekély, participants at the 55th IAEA conference, and seminar participants at the Prague University of Economics, Czech National Bank, and International Monetary Fund.
} 
Contents Page

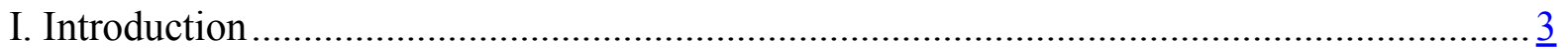

II. A Model of Short-Term Exchange Rate Determination............................................... 4

A. Foreign exchange markets in the short run.........................................................

B. An outline of a theoretical model ................................................................ $\frac{5}{6}$

C. An error-correction framework................................................................ $\underline{6}$

III. Stylized Facts About Foreign Exchange Markets .................................................... $\underline{8}$

A. The liberalization process in Central Europe and market liquidity ........................ $\underline{8}$

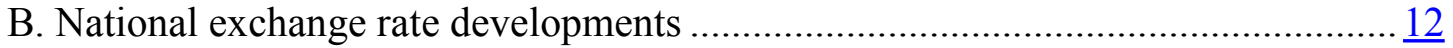

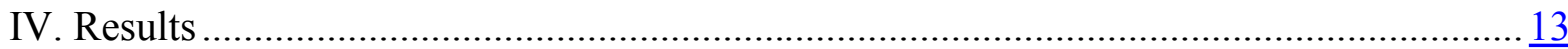

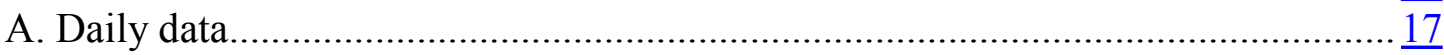

B. Weekly data ..........................................................................................

C. Volatility of Exchange Rate and Central Bank Interventions ............................ 24

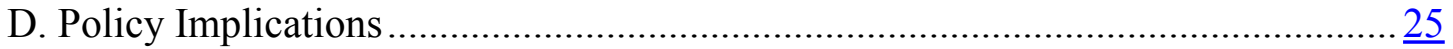

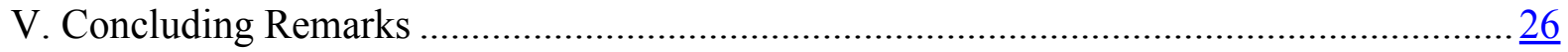

Text Tables

1. Exchange Rate Regimes and Capital Account Developments in Selected

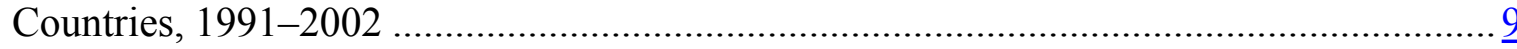

2. Dollar and Euro Exchange Rate Daily Returns: Sample Moments and Kurtosis tests, May 1998-December 2002 .............................................................................. 15

3. Daily Data Without Lagged Dependent Variables...................................................... $\frac{19}{21}$

4. Daily Data With Lagged Dependent Variables ......................................................... $\frac{21}{21}$

5. Weekly Data Without Lagged Dependent Variables ................................................... $\frac{22}{23}$

6. Weekly Data With Lagged Dependent Variables .......................................................23

Figures

1. Time Line of Exchange Rate Determination........................................................... $\underline{6}$

2. Average Daily Foreign Exchange Turnover and Monthly Foreign Exchange Interventions, 1997-2002 ….................................................................................. 10

3. The Czech Republic, Hungary, Poland, and the Slovak Republic: Daily U.S. Dollar and Euro Exchange Rates and the Hodrick-Prescott Filter, May 1998-December 2002.. 14

4. The Czech Republic, Hungary, Poland, and the Slovak Republic: Daily U.S. Dollar and Euro Exchange Rate Returns and Deviations from the Hodrick-Prescott Filter, May 1998-December 2002 ............................................................................ $\frac{16}{18}$

5. Recursive Estimates of $\alpha$ and $\beta$ and Their Two Standard Errors ................................. 18

Annex I. The Farquee-Redding Model of Endogenous Liquidity....................................27

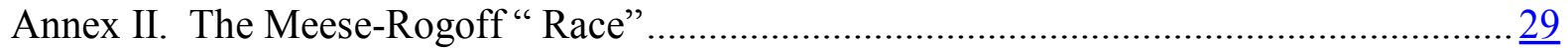

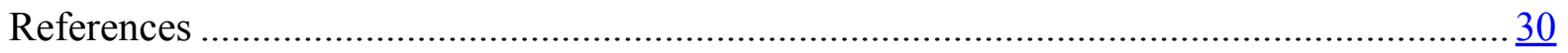




\section{INTRODUCTION}

This paper examines the hypothesis that financial market liberalization can create a basis for more stable exchange rates, as deviations of exchange rates from equilibrium levels, defined here at the Hodrick-Prescott filter, bring forth stabilizing flows of liquidity. This "endogenous liquidity" hypothesis is relevant in the context of the gradual switch from pegs to floats in Central European countries - both to the extent that pegs are more difficult to maintain in liquid markets that respond quickly to participants' changing perceptions and to the extent that such markets create more favorable conditions for a market-determined exchange rate.

Models of foreign exchange markets with endogenously provided liquidity assume that large deviations from longer-term pricing levels attract marginal liquidity into the market, which in turn speeds up the market's return toward its trend-based value (Sarno, 2003). Hence, markets with a large number of informational traders or with deep order books ought to have smaller and shorter deviations of the exchange rate from trend. The fact that endogenous liquidity (the client order flow) can affect market exchange rates is well known, and Faruqee and Redding (1999); Evans and Lyons (2002); Bacchetta and van Wincoop (2003); and Derviz (2003) present theoretical models of endogenous liquidity and foreign exchange microstructure that capture this impact. Empirically, the liquidity effect has been shown by Faruqee and Redding (1999) on a sample of G-7 currencies, and the order flow effect by Evans and Lyons (2002).

We tested the endogenous liquidity hypothesis using daily and weekly exchange rate data for the U.S. dollar and euro against the Czech and Slovak korunas, Hungarian forint, and Polish zloty for the relatively tranquil 1998-2002 period. First, we examined the statistical properties of the series and found excess kurtosis present in the exchange rate returns. Second, we identified transitory movements and trends in the data using the Hodrick-Prescott filter. Finally, we tested the speed-ofadjustment hypothesis within an error-correction framework, finding results comparable to those of Faruqee and Redding (1999).

The results are broadly supportive of the endogenous liquidity hypothesis as the effects of endogenous liquidity are comparable to those of the random walk in exchange rate determination. The results also suggest that early foreign-exchange market and financial-account liberalization might explain the resulting faster-than-average adjustment of some national currencies to short-term deviations from the trend, even if the trend itself may reflect prolonged misalignment. Liberalized and comparatively large markets, such as the Czech Republic, are likely to be more stable than those that are smaller, such as the Slovak Republic, or less fully liberalized ones, such as Hungary in the late 1990s.

Other results indicate that the speed of adjustment of national exchange rates is typically faster vis-à-vis the euro as opposed to the dollar, an intuitive consequence of the region's link to the euro area. These results also seem to be in line with the finding that volatility of exchange rates in the region appears to be only loosely related to the national exchange rate arrangements (Darvas and Szapáry, 2000; Wickham, 2002). In addition, our results imply that central banks should not be overly concerned with short-run volatility of their national exchange rates, given the self-correcting tendencies. 
The paper is organized as follows. After discussing the model and stylized facts, we examine the data properties and outline the empirical techniques. In the following section we present our results. The final section concludes.

\section{A Model of Short-Term Exchange Rate Determination}

Macroeconomists have long observed that exchange rates - both in nominal and real terms - are more volatile than would seem to be justified by conventional macroeconomic models and that the models' short-term explanatory power is limited (Meese and Rogoff, 1983). Clearly, exchange rates can remain fairly long outside of the "fair" value, be it based on fundamental- or equilibrium-based calculations. In contrast, models augmented with microeconomic variables - such as the order flow of foreign exchange in the field of microstructure finance-seem to do much better in the short term. $^{2}$

\section{A. Foreign exchange markets in the short run}

In reality, foreign exchange flows and exchange rates are linked endogenously. Only a fraction of foreign exchange trading is related to a desire to take a particular asset position, for the purposes of either financial investment or foreign trade activity, and the remainder is initiated by some traders providing liquidity to other traders for an expected profit. The expected profit may be based on a sudden departure from a longer-term level of the exchange rate or an increase in the bid-ask spread. Intuitively, large and sudden deviations from the longer-term level of the exchange rate would either activate limit orders set by the existing traders or attract new traders into the market, accelerating the exchange rate's return back to its longer-term level.

Market participants are likely to place large limit orders only in deep and transparent markets. Taking a clue from the theory of finance: "investors tend to invest in instruments they are aware of" (Merton, 1987). On the one hand, knowing that the market for a given currency is deep, as for example where there is a large volume of limit orders on exchange rate movement in either direction away from trend, agents would presumably be less prone to initiate sharp price adjustment to nonfundamental news. On the other hand, the return to longer-term equilibrium values ought to be faster with a deep market, because those limit orders would be activated or new market makers would enter such a market quickly to take advantage of the profit opportunity. ${ }^{3}$ In reality, the former

\footnotetext{
${ }^{2}$ Order flow is defined as the net of buyer-initiated and seller-initiated orders. In conventional macroeconomic models actual trades are typically not related to exchange rate movements. Empirical examples of the link between order flow and daily exchange rate returns were documented for the U.S. dollar/deutsche mark and Czech koruna/euro rates by Evans and Lyons (2002) and Derviz (2003), respectively. Unfortunately, the existing order flow data have been collected in an ad hoc fashion and are yet to be tested in a long-run sample. For example, the Evans and Lyons paper uses a four-month period in 1996 and Derviz's data run from mid-1999 until end-2001.

${ }^{3}$ The empirical literature provides some support for this hypothesis. For example, Devereux and Lane (2003) found that high levels of financial linkages between creditor and developing countries resulted in a lower level of bilateral exchange rate variability.
} 
effect is likely to dominate the latter: the number of foreign exchange dealers in transition countries has been low and stable in the short run. Controlling for exchange rate regimes, foreign exchange market history, central banks' interventions, both open and hidden, and so on, deep markets ought to exhibit faster adjustment to longer-term levels of exchange rates.

In contrast, central bank interventions should not have a significant smoothing impact on the foreign exchange market. Contrary to the conventional view of interventions as an instrument of stabilizing short-term fluctuations, Central European central banks were mostly "leaning against the wind," trying to slow down real exchange rate appreciation. We discuss the evidence in favor of this view later in the paper.

\section{B. An outline of a theoretical model}

How would an economy with endogenous liquidity operate? Faruqee and Redding $(1999,2001)$ and Evans and Lyons (2002) employed three-period, short-term models that share some salient features and we will use a simplified version thereof to motivate the empirical work in our paper. Arguably, the Evans and Lyons model is geared toward explaining intra-day movements in the exchange rate, while Faruqee and Redding are concerned with somewhat longer periods. However, the adjustment in both models is effected through similar processes.

Consider a three-period economy in which trading influences the price of foreign currency (the model is derived formally in Annex I). Ignoring differences between the direct and brokered markets, the economy is populated by two types of agents. First, noninformational ("noise") traders who trade primarily for purposes of financial investment or foreign trade activity and may push the exchange rate away from the best estimate of the liquidation price $\left({ }_{i} E P_{3}\right)$ in each period. These traders do not have a longer-term view of the exchange rate and typically buy foreign exchange at a given price. Second, informational traders (or market makers), who provide desired liquidity in exchange for an expected profit to be realized in period 3 when the market is liquidated. These traders speculate, with a view of returning the rate to a market clearing level. ${ }^{4}$

The asset will have a liquidation price $\left(P_{3}\right)$ in the final period that is not known with certainty prior to $T_{3}$. The asset is being traded in the first two periods, $T_{1}$ and $T_{2}$, resulting in prices $P_{1}$ and $P_{2}$, gradually improving the precision of the estimate of $P_{3}$, i.e., ${ }_{1} E P_{3}$ and ${ }_{2} E P_{3}$. The first- and secondperiod estimates of $P_{3}$ are normally distributed around $P_{3}$ with posterior sample variances of $\sigma_{1}^{2}$ and $\sigma_{2}^{2}$, respectively, such that $\sigma_{1}^{2} \geq \sigma_{2}^{2}$. Naturally, if noninformational traders' orders were completely absent, the second-period price would be equal to the expectation of the third-period price. The resulting time line of exchange rate determination is described in Figure 1.

\footnotetext{
${ }^{4}$ Which particular instruments are used by individual market participants is a side issue, depending primarily on the structure of individual markets.
} 
Figure 1. Time Line of Exchange Rate Determination

\begin{tabular}{|c|c|c|c|c|c|c|c|}
\hline Period $1\left(T_{1}\right) \mathrm{P}$ & & & & $\operatorname{eriod} 2\left(T_{2}\right) \mathrm{P}$ & & & eriod $3\left(T_{3}\right)$ \\
\hline $\begin{array}{l}\text { First-period } \\
\text { informational } \\
\text { traders enter the } \\
\text { market and limit } \\
\text { orders are set }\end{array}$ & $\begin{array}{l}\text { The net } \\
\text { demand of } \\
\text { "noise" } \\
\text { traders is } \\
\text { announced }\end{array}$ & $\begin{array}{l}{ }_{1} E P_{3} \text { is } \\
\text { revealed }\end{array}$ & $\begin{array}{l}\text { Public } \\
\text { trading } \\
\text { results in a } \\
\text { rate } P_{1}\end{array}$ & $\begin{array}{l}\text { Second-period } \\
\text { informational } \\
\text { traders enter the } \\
\text { market and limit } \\
\text { orders are set }\end{array}$ & $\begin{array}{l}{ }_{2} E P_{3} \text { is } \\
\text { revealed }\end{array}$ & $\begin{array}{l}\text { Public } \\
\text { trading } \\
\text { results in a } \\
\text { rate } P_{2}\end{array}$ & $\begin{array}{l}\text { The market is } \\
\text { liquidated at a } \\
\text { price } P_{3}\end{array}$ \\
\hline
\end{tabular}

The model assumption of gradual price discovery $\left(\sigma_{1}^{2} \geq \sigma_{2}^{2}\right)$ implies that the expected exchange rate will drift toward its longer-term value. However, the speed of adjustment is endogenous: the bigger the absolute value of the discrepancy between the expected final and realized first-period exchange rates $\left({ }_{1} E P_{3}-P_{1} \mid\right)$, the deeper the order book will be in the second period and the faster the reversion to $P_{3}$.

\section{An error-correction framework}

The principal implication of the Faruqee-Redding model is that the speed of adjustment of exchange rates toward their fundamental values is proportionately higher when the deviation from the trend equilibrium value level is large and the order book is deep. While the former hypothesis is testable, the latter is not, given the absence of long-run order flow data.

The empirical testing of exchange rate developments consists of two parts. First, defining $e$ as the $\log$ of the exchange rate, we separate its longer-term trend level $(f)$, which is presumably affected by fundamental factors, from the effects of transitory demand $(n)$ :

$$
e=f+n
$$

The decomposition was done using univariate techniques, namely the Hodrick-Prescott filter. ${ }^{5}$ The filter was used to characterize the trend portion of the exchange rate, and the difference from the actual exchange rate was used to characterize the transitory demand.

The pros and cons of using the above univariate techniques are obvious. First, we avoid the troublesome joint testing of the endogenous liquidity hypothesis and an ad hoc chosen model of long-term exchange rate determination as in Meese and Rogoff (1983). Second, the HodrickPrescott filter sidesteps the problem of prolonged misalignment - the medium-term exchange rate is what we observe in the data. The flip side is, of course, that filtering away short-term fluctuations is not equivalent to the fundamental-based exchange rate. Moreover, filtering does not shed light on

\footnotetext{
${ }^{5}$ We use the common rule for determining the bandwidth parameter $\lambda$ for the Hodrick-Prescott filter: 100 times its frequency-squared. Hence, $\lambda$ takes the value 14,400, 260,100, and 6,250,000 for monthly, weekly, and daily data, respectively. The results using the kernel-based smoother (the Epanechnikov kernel) are not materially different from the Hodrick-Prescott filter, including spurious autocorrelation (Cogley and Nason, 1995).
} 
the nature of the trend process: the underlying trend can be stochastic, supporting an I(1) variable, or deterministic with broken trend and supporting an I(0) variable. Applying the selected filters we impose a fixed speed of adjustment of the trend to actual developments in all periods and all countries. ${ }^{6}$ On balance, however, we see the disadvantages of joint testing as more serious than those of mechanical filtering.

Second, we explore the nature of the short-term fluctuations. The model predicts that the transitory departure from the trend ought to be short-lived and the exchange rate would revert in expectation to the trend value of the exchange rate (Annex I):

$$
\left|{ }_{t} E\left[n_{t+1}\left(n_{t}\right)\right]\right|<\left|n_{t}\right|,
$$

where the expected value of the transitory component of the exchange rate in time $t+1$ is conditional on its value in time $t$.

Moreover, the model predicts the nonlinear mean reversion to be positively related to the initial value of the short-term deviation from trend $(n)$ :

$$
\frac{d\left[n_{t}-{ }_{t} E\left(n_{t+1}\right)\right]}{d n_{t}}>0
$$

In other words, the error correction term in the numerator ought to be increasing in the initial departure from the trend. ${ }^{7}$

The above univariate error-correction mechanism can be tested in a simple equation:

$$
\Delta e_{t}=\alpha n_{t-1}+\beta\left(n_{t-1}\right)^{3}+\sum_{1}^{x} \delta_{i} \Delta e_{t-i}+\varepsilon_{t}
$$

where $n_{t}=e_{t}-f_{t}$ is the difference from the Hodrick-Prescott filter; the parameter $\alpha$ captures the proportional part of the mean reversion (error-correction) process; and the parameter $\beta$ captures the

\footnotetext{
${ }^{6}$ For example, the market may be characterized by two or more adjustment processes: one through private agent interactions and the other through central bank interventions. Presumably, the monetary authority is concerned less with the speed of adjustment of the nominal exchange rate than with finding a particular level of the real exchange rate.

${ }^{7}$ Granger and Siklos (1997) addressed a similar problem, namely that the cointegrating relationship can be nonlinear in nature and, moreover, depend on the nature of the policy regime in place. See also the review of nonlinear adjustment models in Sarno (2003).
} 
additional mean reversion owing to the endogenous liquidity hypothesis. ${ }^{8}$ The advantage of a cubic term - as opposed to a quadratic term - is that it preserves the sign of the transitory component. In addition, equation 4 can include lagged dependent variables and, hence, it becomes a direct test of the random walk hypothesis of exchange rate.

Given that mean reversion entails negative autocorrelation, both the proportional and additional error-correction mechanisms imply negative expected values for $\alpha$ and $\beta$. Should the endogenous liquidity hypothesis be rejected, the estimated value of $\beta$ would have to be zero. Hence, in the subsequent sections we will test both the sign and significance of the $\alpha$ and $\beta$ coefficients for different country series and time periods. Of course, the two error-correction processes are not independent: an identically fast return to trend can be achieved either through "high" $\alpha$ and "low" $\beta$, or vice versa, "low" $\alpha$ and "high" $\beta$. While the former example would portray a deep, fast reacting market, the latter would portray a shallow market, which needs a major departure from trend to attract additional liquidity. Although the speed of adjustment could be the same in those examples, the paths of the exchange rate would differ. The null hypothesis of the random walk implies that $\delta_{i}$ is equal to zero.

\section{Stylized Facts About Foreign Exchange Markets}

\section{A. The liberalization process in Central Europe and market liquidity}

Although the national exchange rate arrangements differed in the initial stages of transition, the authorities in the Czech Republic, Hungary, Poland, and the Slovak Republic (also known as the Visegrád Four) eventually adopted managed floating arrangements, gradually building up liquidity in their foreign exchange markets (Table 1). ${ }^{9}$ Notwithstanding the similarity in the choice of the arrangement during 2000-2002, the volume of trading on those markets differed substantially (Figure 2). ${ }^{10}$ This is certainly related to the history of the market: for example, in the mid-1990s the Czech market was exposed to large privatization-related foreign exchange trading with substantial exchange rate risk, necessitating early development of the derivative market, as

\footnotetext{
${ }^{8}$ An obvious disadvantage of this specification is multicolinearity between $n$ and $(n)^{3}$. It seems to be a relatively small price to pay: we loose some efficiency, but our estimated coefficients remain unbiased.

${ }^{9}$ This classification is based on self-assessment by individual countries. Reinhart and Rogoff (2002) or Bofinger and Wollmershaeuser (2001) have shown that the actual behavior of exchange rates can be consistent with regimes different from those declared officially. See also Ghosh et al. (2003) for a critique of model-based assessments of exchange rate regimes.

${ }^{10}$ Nevertheless, the data exhibit a fair amount of spatial correlation, confirming the intuitive assumption that all four Central European currencies were subject to similar exchange rate shocks. See Kóbor and Szekély (forthcoming) for a model of two-regime switching exchange-rate process in Visegrád Four countries. They find that two pair-wise correlations, between the Czech and Slovak korunas and between the forint and zloty, dominate the four-way relationship.
} 


\section{Table 1. Exchange Rate Regimes and Capital Account Developments in Selected Countries, $1991-2002^{1}$}

\begin{tabular}{|c|c|c|c|c|c|}
\hline Country I & od & De jure regime B & and & $\begin{array}{c}\text { Periodic } \\
\text { Devaluations }\end{array}$ & $\begin{array}{l}\text { Capital Account } \\
\text { Developments }\end{array}$ \\
\hline \multirow{2}{*}{$\begin{array}{l}\text { Czech } \\
\text { Republic }\end{array}$} & $\begin{array}{l}\text { January 1993- } \\
\text { May } 1997\end{array}$ & Peg & $\begin{array}{l}+/-0.5 \text { percent, } \\
\text { changed to } \\
+/-7.5 \text { percent in } \\
\text { February } 1996 \\
\end{array}$ & No & \multirow{2}{*}{$\begin{array}{l}\text { Fast deregulation; liberal } \\
\text { regime (1999 Foreign } \\
\text { Exchange Act); "hands } \\
\text { off" approach to } \\
\text { regulation of financial } \\
\text { markets }\end{array}$} \\
\hline & $\begin{array}{l}\text { From May 27, } \\
1997\end{array}$ & $\begin{array}{l}\text { Float (with } \\
\text { discretionary } \\
\text { interventions) }\end{array}$ & No ... & & \\
\hline \multirow{3}{*}{ Hungary $^{2}$} & $\begin{array}{l}\text { January 1991- } \\
\text { February } 1995\end{array}$ & Soft peg & $\begin{array}{l}\text { Gradually changed } \\
\text { from nil to }+/-2.25 \\
\text { percent in } \\
\text { December } 1994\end{array}$ & $\begin{array}{l}\text { Yes, } 22 \\
\text { devaluations }\end{array}$ & \multirow{3}{*}{$\begin{array}{l}\text { Closely regulated until } \\
\text { June } 2001 \text { Government } \\
\text { decree; "hands on" } \\
\text { approach to regulation of } \\
\text { financial markets }\end{array}$} \\
\hline & $\begin{array}{l}\text { March 1995- } \\
\text { September } 2001\end{array}$ & $\begin{array}{l}\text { Crawling peg } \\
\text { (pre-announced) }\end{array}$ & $\begin{array}{l}+/-2.25 \text { percent, } \\
\text { change to }+/-15 \\
\text { percent in May } \\
2001\end{array}$ & Yes & \\
\hline & $\begin{array}{l}\text { From October 1, } \\
2001\end{array}$ & $\begin{array}{l}\text { Float (with } \\
\text { discretionary } \\
\text { interventions) }\end{array}$ & $+/-15$ percent & $\ldots$ & \\
\hline \multirow[t]{2}{*}{ Poland $^{3}$} & $\begin{array}{l}\text { October 1991- } \\
\text { March } 2000\end{array}$ & $\begin{array}{l}\text { Crawling peg } \\
\text { (pre-announced) }\end{array}$ & $\begin{array}{l}\text { Gradually changed } \\
\text { from nil to }+/-15 \\
\text { percent in } \\
\text { December } 1994\end{array}$ & Yes & \multirow{2}{*}{$\begin{array}{l}\text { Slow progress until the } \\
\text { late } 1990 \text { s, liberalization } \\
\text { in January 2000; "hands } \\
\text { on" regulation of financial } \\
\text { markets; markets put off } \\
\text { by the fiscal-monetary } \\
\text { mix }\end{array}$} \\
\hline & $\begin{array}{l}\text { From April 12, } \\
2000\end{array}$ & Independent float & No & $\cdots$ & \\
\hline \multirow[t]{2}{*}{$\begin{array}{l}\text { The } \\
\text { Slovak } \\
\text { Republic }\end{array}$} & $\begin{array}{l}\text { January } 1993- \\
\text { September } 1998\end{array}$ & Peg & $\begin{array}{l}\text { Extended in } \\
\text { several steps from } \\
+/-1.5 \text { percent in } \\
\text { January } 1996 \\
\text { to }+/-7 \text { percent in } \\
\text { January } 1997 \\
\end{array}$ & No & \multirow{2}{*}{$\begin{array}{l}\text { Similar steps if slower } \\
\text { pace than in the Czech } \\
\text { Republic (1999 } \\
\text { Amendment to Foreign } \\
\text { Exchange Act); little } \\
\text { outside interest in Slovak } \\
\text { koruna paper }\end{array}$} \\
\hline & $\begin{array}{l}\text { From October 1, } \\
1998\end{array}$ & $\begin{array}{l}\text { Float (with } \\
\text { discretionary } \\
\text { interventions) }\end{array}$ & No ... & & \\
\hline
\end{tabular}

Sources: Darvas and Szapáry (2000); Schardax (2002); and central banks' official web sites.

1 This table contains an official classification of the national exchange rate arrangement as declared by the national monetary authorities. However, Reinhart and Rogoff (2002) have shown that de jure as opposed to de facto exchange rate arrangements can differ. For example, the early Czech, Hungarian, and Slovak pegs are reclassified as crawls, Poland's crawling peg during 1991-95 is reclassified as a dual market rate arrangement, and so on.

2 Step devaluation (9 percent) in March 1995. Schardax (2002) argued that the widening of the intervention band, followed in October 2001 by the adoption of an inflation targeting regime, is equivalent to a managed floating regime.

3 Step devaluation (6 percent) in December 1995. 
Figure 2. Average Daily Foreign Exchange Turnover and Monthly Foreign Exchange Interventions, 1997-2002 1/
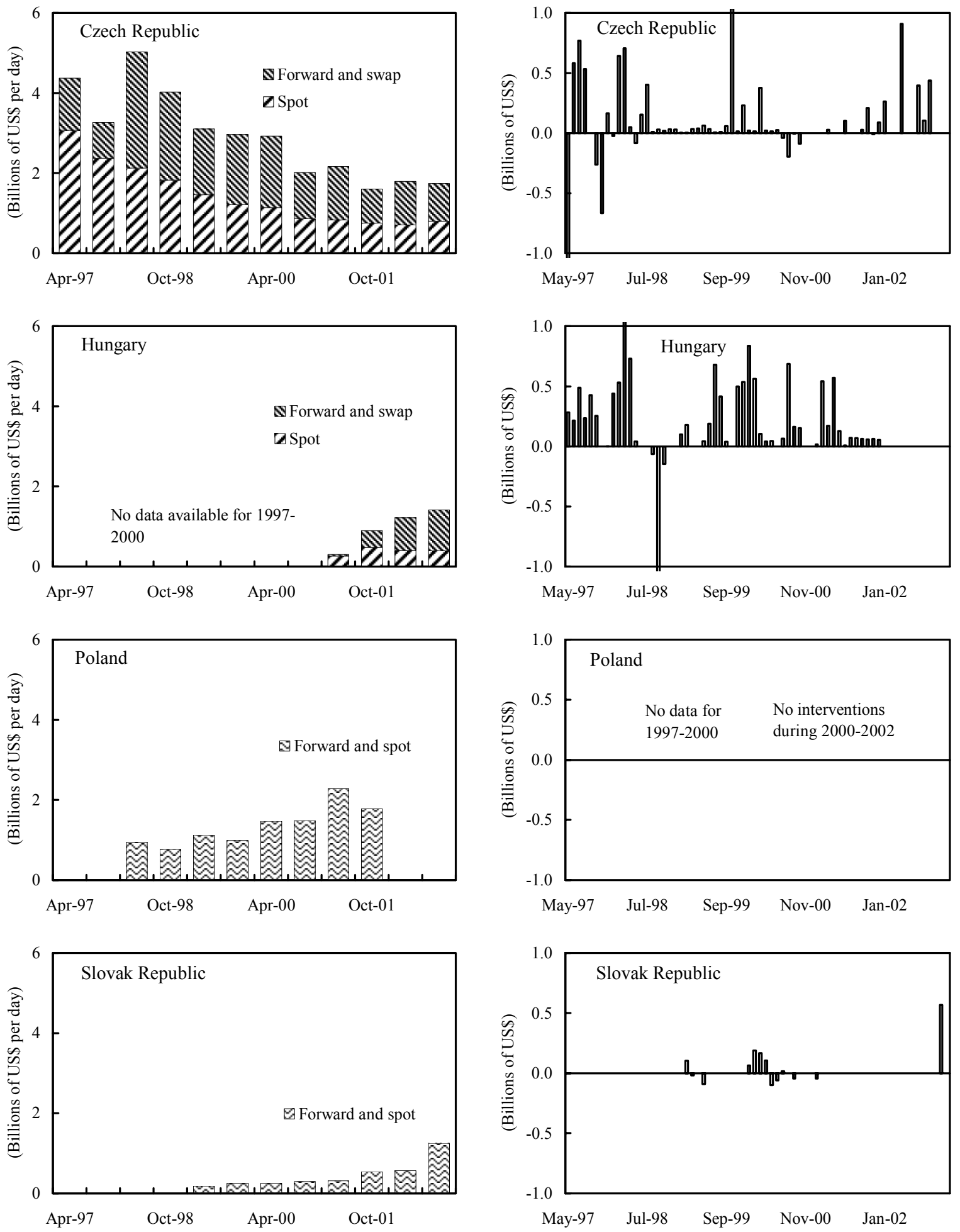

Source: National central bank websites.

1/ Average daily foreign exchange turnover (for months of April and October) and monthly foreign exchange intervention data are in the left and right columns, respectively. 
compared to the less exposed market in the Slovak Republic or the tightly controlled Hungarian market. In terms of market size, the Czech koruna was the most heavily traded, while the market for the Slovak koruna was the thinnest. The Polish market was large in levels, but in relation to the size of the Polish economy it was comparable to the Slovak market. ${ }^{11}$

Our sample countries differed also in terms of capital-flow liberalization. In terms of institutional control, Czech financial-account transactions were freed in the second half of the 1990s and the koruna was floated subsequently. These developments resulted in large daily turnovers and fast-growing derivative markets. The Slovak Republic followed a similar path, although with much slower turnover growth. In contrast, Hungary and Poland maintained narrow-band crawling peg regimes and both formal and informal capital-flow controls until the early 2000s, with correspondingly small turnover.

We also looked at two other measures of institutional liberalization and market depth, national currency Eurobonds and real interest rates. First, the volume of the eurobond market in the national currency. While the Czech koruna-denominated market has had around 40 new, private issues per year for the past six years (with outstanding eurobonds of more than US\$3 billion), forint-denominated eurobonds were first issued in 2001 (with an outstanding volume of about US $\$ 100$ million). No Slovak-koruna denominated eurobonds have been issued yet, showing the Slovak Republic's slow progress in foreign exchange market development, and no summary data are available for Poland. Second, short-term real interest rates seems to tell a very similar story. The 2002 average real one-month interbank rate of the Czech koruna was 1.6 percent, practically identical to German interbank rate of the same maturity. While the Hungarian rate was somewhat higher at 3.5 percent, the Slovak rate rose to 4.3 percent, and the Polish rate peaked at almost 7 percent.

Unfortunately, none of the above indicators provides an explicit measure of foreign exchange market liquidity and depth. For example, trading volumes are only imperfect substitutes, dependent on the chosen structure of the market: ceteris paribus, a market with multiple market makers is going to record much higher trading volume than a broker-based market (Bofinger and Wollmershaeuser, 2001). High trading volumes in mid-1998 in the Czech Republic or end-2002 in Hungary may indicate periods of market turmoil rather than overall high liquidity. Similarly, the number of tradable instruments is only an indication of potential liquidity and, for example, the volumes on the domestic-currency eurobond markets have been rather thin. Finally, real interest rates may have more to do with overall macroeconomic conditions and policy response to trend real appreciation that with a precise measurement of market depth.

The available data provide an indication of market liquidity, not a precise measure thereof. These data suggest that the Czech market was the most liquid from the outset, irrespective of the subsequent decline in turnover. The remaining markets are less liquid, although the Hungarian market picked up substantially following the floating of the forint. In terms of the empirical model

${ }^{11}$ Poland's population in the late 1990s was almost 40 million, as compared to about 10 million for the Czech Republic and Hungary and 5 million for the Slovak Republic. See also other comparisons at Bofinger and Wollmershaeuser (2001). 
defined above, the estimates of the nonlinear speed of adjustment, $\beta$, ought to be high in absolute terms for the Czech koruna for the early data and lower in the later data, possibly accompanied by increasing absolute-value $\alpha$ s. In the remaining countries, the estimated absolute-value $\beta$ s might be increasing in time as their currencies were floated.

\section{B. National exchange rate developments}

End-period daily, weekly, and monthly exchange rate data from May 1998 until December 2002 were collected. The data were expressed in foreign-currency units (U.S. dollar and euro) per unit of domestic currency and logarithms were taken of all series. All the series were found to be nonstationary, of order I(1). The estimated coefficient of the lagged variable in the augmented Dickey-Fuller (ADF) regressions was typically around 0.99 , indicating that the series follows a random walk. The weekly Slovak koruna series appeared to be stationary, although the estimated coefficient of the lagged variable remained high at around 0.90-0.91.

We observed that the nominal volatility in our sample does not seem to be linked directly to the exchange rate arrangement in place (Figure 3 and 4). For example, both the dollar and euro deviations of the Czech currency from the trend under the floating arrangement appear to be smaller than the Polish currency deviations under the dollar/euro basket crawling peg arrangement. Indeed, the only period of markedly low volatility in our sample was the one-year Hungarian experiment with a tight crawling peg vis-à-vis the euro from about December 1999 until November 2000, following the forint crawling peg against the dollar/euro basket.

The dependent variable for the error-correction mechanism suggested above is the differenced series, and its properties are shown in Table 2. ${ }^{12}$ All differenced series were found to be stationary, that is, of order I(0), and the estimated coefficients of the lagged variable in the ADF test were invariantly smaller than 0.20 . A few observations are worth noting. First, the volatility of the euro exchange rates was typically lower than that of dollar rates, as most foreign exchange trading has been done in deutsche mark and subsequently in euro, an intuitive consequence of the region's trading and investment link to Western Europe. The Polish zloty is an outlier: the estimated volatility vis-à-vis the dollar and euro are essentially identical, even after the dollar/euro basket was called off in early 2000. It appears that dealers in the zloty market look up to the dollar as much as to the euro, perhaps because these traders are U.S. based (Panthaki, 2004).

Second, all daily and most weekly and monthly series fail the normality test at the 1 percent significance level, primarily on account of excess kurtosis present in the data. ${ }^{13}$ The distributions of

\footnotetext{
${ }^{12}$ We confirmed the presence of cointegrating relationships between the exchange rate in levels and its Hodrick-Prescott filter using the Johansen and Juselius (1990) technique and observed that the speed of adjustment is fairly slow. Both results are intuitive: first, the Hodrick-Prescott filter is a dynamic measure of central tendency and, second, the actual exchange rates hovered above or below its trend for relatively long periods.

${ }^{13}$ The outliers are the weekly dollar series for Hungary and the Slovak Republic and also the monthly euro series for the Slovak Republic. As discussed earlier, however, the dollar returns are
} 
the differenced series have "fat tails," that is, we observe a number of surprisingly high daily returns, a typical property of most high-frequency financial data (Figure 4). Somewhat surprisingly, however, these results differ very little whether we look at the full sample - during which some countries pegged or crawled - or focus only on the post-October 2001 sample during which all countries floated. This finding is consistent with the Darvas and Szapáry (2000) argument of exchange rate arrangement irrelevancy for exchange rate volatility; see also Wickham (2002).

We observed that the mean duration of a departure from the trend was around 40 trading days, consistent with a slow speed of adjustment in the cointegrating relationship that was observed between the raw series and its Hodrick-Prescott filter (Figure 4). Each currency's exchange rate had 20-30 periods when it remained above or below the trend (Hodrick-Prescott filter) for at least 5 trading days. Of the four currencies under consideration, during 2002 the Czech koruna had the highest number of such transitory deviations vis-à-vis the euro trend (seven) and their average duration was the shortest (less than 30 trading days). In contrast, the Slovak koruna had only three deviations from the trend, but they lasted on average four months. The forint and zloty were somewhere in between with 5-6 deviations. Most of those events were consistent with the hypothesis of endogenous liquidity provision - a gradual buildup of deviations from the trend followed, from a certain moment, with a swift adjustment back to the trend.

\section{Results}

We find that the speed of adjustment in our sample is directly comparable to that of G-7 countries in Faruqee and Redding (1999). As predicted, the Czech koruna adjustment was the fastest and the forint adjustment picked up speed considerably toward the end of the sample period.

The results of estimating equation (4) by ordinary least squares for both the U.S. dollar and euro exchange rates in each of the four countries (the Czech Republic, Hungary, Poland, and the Slovak Republic) are shown in Tables 3-6. In addition to presenting the results for the daily and weekly series in Tables 3-4 and 5-6, respectively, we took also into account the different exchange rate regimes. Equation 4 is thus estimated for three sample periods: (i) May 1998-December 2002, corresponding to the period of the float of the Czech koruna; (ii) May 2000-December 2002, corresponding to the period of the float of the Polish zloty and Slovak koruna; and (iii) October 2001-December 2002, corresponding to the period of the float of the forint. Annex II compares outof-sample forecasting accuracy (Meese and Rogoff, 1983) of the various versions of Equation 4 and finds that the pure random walk model performs quite similarly to the Faruqee-Redding model without lagged variables, but that the latter model with lagged variables is superior to either model.

mostly a product of cross-rate developments. In addition, the weekly and monthly series are short with only 234 and 56 observations, respectively. 
Figure 3. The Czech Republic, Hungary, Poland, and the Slovak Republic: Daily U.S. Dollar and Euro Exchange Rates and the Hodrick-Prescott Filter, May 1998-December 2002 1/
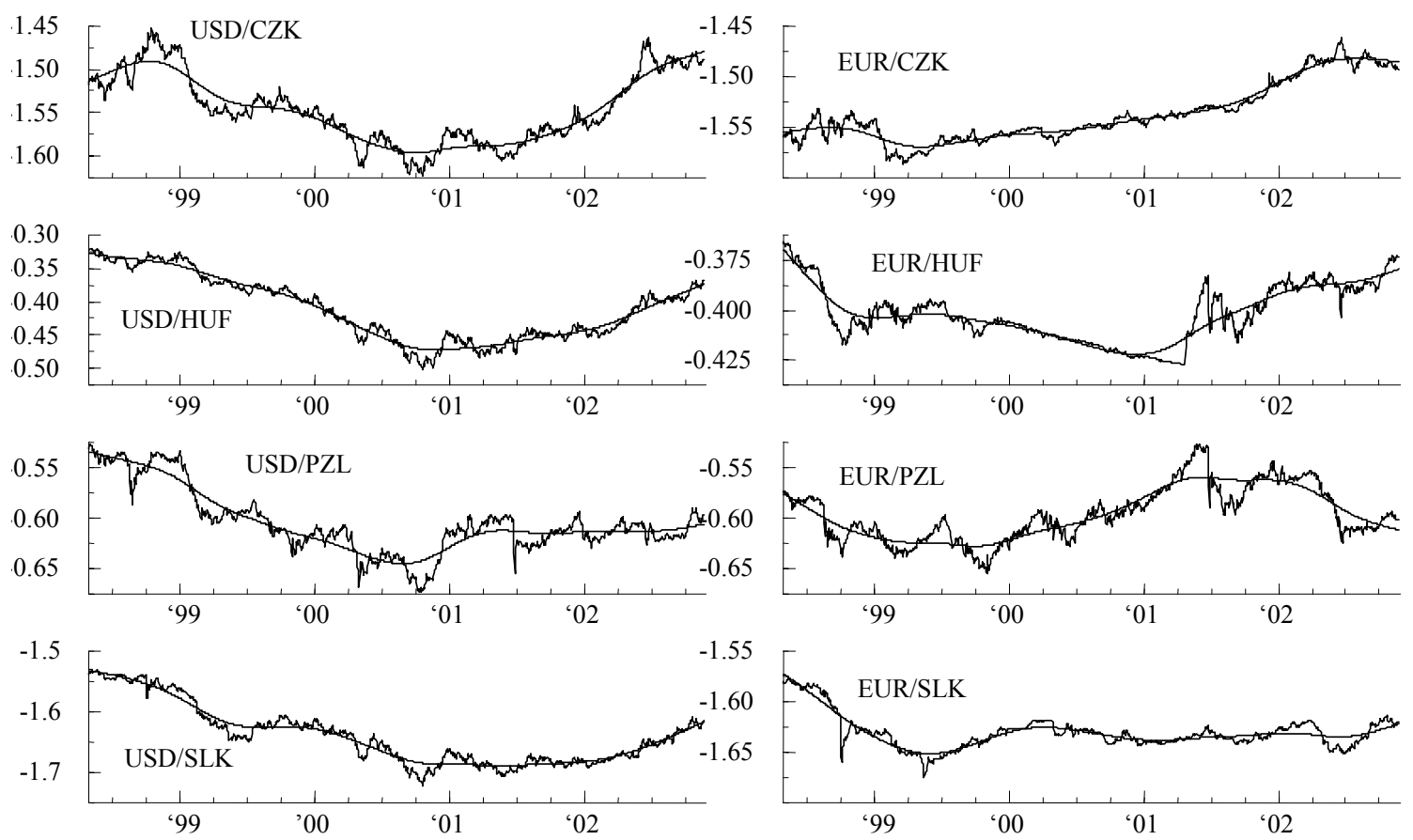

Source: Czech National Bank; author's calculations.

1/ The Hodrick-Prescott filter parameter $\lambda$ has been set to $6,250,000$. All data are in logs. 
Table 2. Dollar and Euro Exchange Rate Daily Returns: Sample Moments and Kurtosis tests, May 1998-December 2002

\begin{tabular}{|c|c|c|c|c|c|c|c|c|}
\hline & \multicolumn{2}{|c|}{ Czech Republic } & \multicolumn{2}{|c|}{ ungary } & \multicolumn{2}{|c|}{ Poland } & \multicolumn{2}{|c|}{ Slovak Republic } \\
\hline & Dollar Eu & o & Dollar & Euro & Dollar Eur & o & Dollar Eur & o \\
\hline \multicolumn{9}{|c|}{ A. Daily data $(n=1,165)$} \\
\hline Mean & $2.548 \mathrm{E}-5$ & $5.738 \mathrm{E}-5$ & $-3 \quad .837 \mathrm{E}-5$ & $-6.472 \mathrm{E}-5$ & $-5 \quad .570 \mathrm{E}-5$ & $-2.381 \mathrm{E}-5$ & $-6 \quad .586 \mathrm{E}-5$ & $-3.397 \mathrm{E}-5$ \\
\hline Std. Deviation & 0.00334 & 0.00202 & 0.00290 & 0.00159 & 0.00315 & 0.00349 & 0.00317 & 0.00174 \\
\hline Skewness ${ }^{1}$ & 0.0585 & -0.3171 & 0.0185 & -1.3463 & -0.5352 & -0.6227 & -0.3409 & -5.1425 \\
\hline Excess kurtosis $^{2}$ & 1.3052 & 5.3962 & 1.7769 & 18.792 & 10.359 & 8.7817 & 4.5902 & 88.746 \\
\hline Normality test $^{3}$ & $61.99 * * *$ & $503.9 * * *$ & $103.4 * * *$ & $1514.8 * * *$ & $1514.4 * * *$ & $841.8^{* * *}$ & $393.2 * * *$ & $1066.2 * * *$ \\
\hline \multicolumn{9}{|c|}{ Of which: May 1998-September $2001(\mathrm{n}=881)$} \\
\hline Mean & $-5.482 \mathrm{E}-5$ & $3.770 \mathrm{E}-5$ & $-1 \quad .437 \mathrm{E}-4$ & $-5.118 \mathrm{E}-5$ & $-1 \quad .063 \mathrm{E}-4$ & $-1.351 \mathrm{E}-5$ & $-1 \quad .594 \mathrm{E}-4$ & $6.692 \mathrm{E}-5$ \\
\hline Std. Deviation & 0.00341 & 0.00197 & 0.00296 & 0.00160 & 0.00337 & 0.00369 & 0.00330 & 0.00183 \\
\hline Skewness ${ }^{1}$ & -0.0565 & -0.6455 & -0.0222 & -1.7219 & -0.4740 & -0.6543 & -0.4130 & -5.8168 \\
\hline Excess kurtosis $^{2}$ & 0.9731 & 6.5395 & 1.8247 & 23.586 & 10.319 & 9.127 & 4.959 & 94.834 \\
\hline Normality test ${ }^{3}$ & $28.88 * * *$ & $401.99^{* * *}$ & $81.87 * * *$ & $1206.4 * * *$ & $860.74 * * *$ & $657.92 * * *$ & $318.37 * * *$ & $719.59 * * *$ \\
\hline \multicolumn{9}{|c|}{ October 2001-December $2002(\mathrm{n}=284)$} \\
\hline Mean & $2.907 \mathrm{E}-4$ & 9.904E-5 & 2. $907 \mathrm{E}-4$ & $9.904 \mathrm{E}-5$ & 6. $473 \mathrm{E}-5$ & $-1.269 \mathrm{E}-4$ & 2. $589 \mathrm{E}-4$ & $6.733 \mathrm{E}-5$ \\
\hline Std. Deviation & 0.00313 & 0.00220 & 0.00269 & 0.00148 & 0.00242 & 0.00278 & 0.00272 & 0.00142 \\
\hline Skewness $^{1}$ & 0.5454 & 0.4146 & 0.2576 & -0.0893 & -0.7947 & -0.3767 & 0.1931 & -0.0981 \\
\hline Excess kurtosis $^{2}$ & 2.4235 & 2.6295 & 1.3477 & 2.0471 & 1.9089 & 1.0555 & 0.8656 & 1.6972 \\
\hline Normality test ${ }^{3}$ & $34.98 * * *$ & $44.91 * * *$ & $18.05 * * *$ & $36.83 * * *$ & $25.62 * * *$ & $12.41 * * *$ & $9.52 * * *$ & $27.54 * * *$ \\
\hline \multicolumn{9}{|c|}{ B. Weekly data $(n=234)$} \\
\hline Mean & $8.710 \mathrm{E}-5$ & $2.843 \mathrm{E}-4$ & $-2 \quad .235 \mathrm{E}-4$ & $-2.638 \mathrm{E}-5$ & $-3 \quad .148 \mathrm{E}-4$ & $-1.118 \mathrm{E}-5$ & 3. $609 \mathrm{E}-4$ & $-1.638 \mathrm{E}-4$ \\
\hline Std. Deviation & 0.00798 & 0.00432 & 0.00658 & 0.00320 & 0.00649 & 0.00647 & 0.00679 & 0.00418 \\
\hline Skewness $^{1}$ & 0.1389 & -0.9793 & 0.2010 & -1.0245 & -0.9177 & -1.2818 & 0.1892 & -2.2137 \\
\hline Excess kurtosis $^{2}$ & 3.6668 & 6.0544 & 0.00561 & 8.3269 & 2.9452 & 3.9448 & 0.00260 & 15.786 \\
\hline Normality test ${ }^{3}$ & $73.65^{* * *}$ & $78.81 * * *$ & 1.642 & $129.1 * * *$ & $29.94 * * *$ & $43.83 * * *$ & 1.460 & $99.25^{* * *}$ \\
\hline \multicolumn{9}{|c|}{ C. Monthly data $(n=56)$} \\
\hline Mean & $5.301 \mathrm{E}-4$ & $1.193 \mathrm{E}-3$ & $-7.982 \mathrm{E}-4$ & $1.351 \mathrm{E}-4$ & $-1 \quad .159 \mathrm{E}-3$ & $4.950 \mathrm{E}-4$ & $-1 \quad .370 \mathrm{E}-3$ & $-7.066 \mathrm{E}-4$ \\
\hline Std. Deviation & 0.01644 & 0.00947 & 0.01121 & 0.00661 & 0.01456 & 0.01383 & 0.01127 & 0.00694 \\
\hline Skewness $^{1}$ & 0.3886 & -0.4582 & 0.3912 & 0.6595 & -0.4535 & -1.2049 & 0.0888 & -0.3084 \\
\hline Excess kurtosis $^{2}$ & 0.8399 & 2.2613 & 0.11842 & 3.2121 & 1.90459 & 1.47035 & -0.34811 & -0.10951 \\
\hline Normality test ${ }^{3}$ & $4.417 *$ & $13.54 * * *$ & 1.748 & $18.77 * * *$ & $10.751 * *$ & $16.49 * * *$ & 0.091 & 1.05 \\
\hline
\end{tabular}

Source: Author's calculations.

${ }^{1}$ The skewness statistic $\theta_{1}$ of a va riable $x$ is calculated as $\theta_{1}=\frac{E\left[(x-\mu)^{3}\right]}{(\operatorname{Var}[x])^{3 / 2}}$, where $\mu$ is the sample mean and the standard deviation is based on $1 /$ T. In normal distributions with no skewness the $\theta_{1}$ statistic would be zero.

${ }^{2}$ The excess kurtosis statistic $\theta_{2}$ of a variable $x$ is calculated as $\theta_{2}=\frac{E\left[(x-\mu)^{4}\right]}{(\operatorname{Var}[x])^{2}}-3$, where $\mu$ is the sample mean and the standard deviation is based on $1 / \mathrm{T}$. In normal distributions with no excess kurtosis the $\theta_{2}$ statistic would be zero.

3 The normality test is distributed as $\chi^{2}(2)$. The significance level of the rejection of the hypothesis that the variable under consideration is distributed as a normal variable at 1,5 , and 10 percent are denoted by '***', '**', and '*', respectively. 
Figure 4. The Czech Republic, Hungary, Poland, and the Slovak Republic: Daily U.S. Dollar and Euro Exchange Rate Returns and Deviations from the Hodrick-Prescott Filter,

May 1998-December 2002 1/
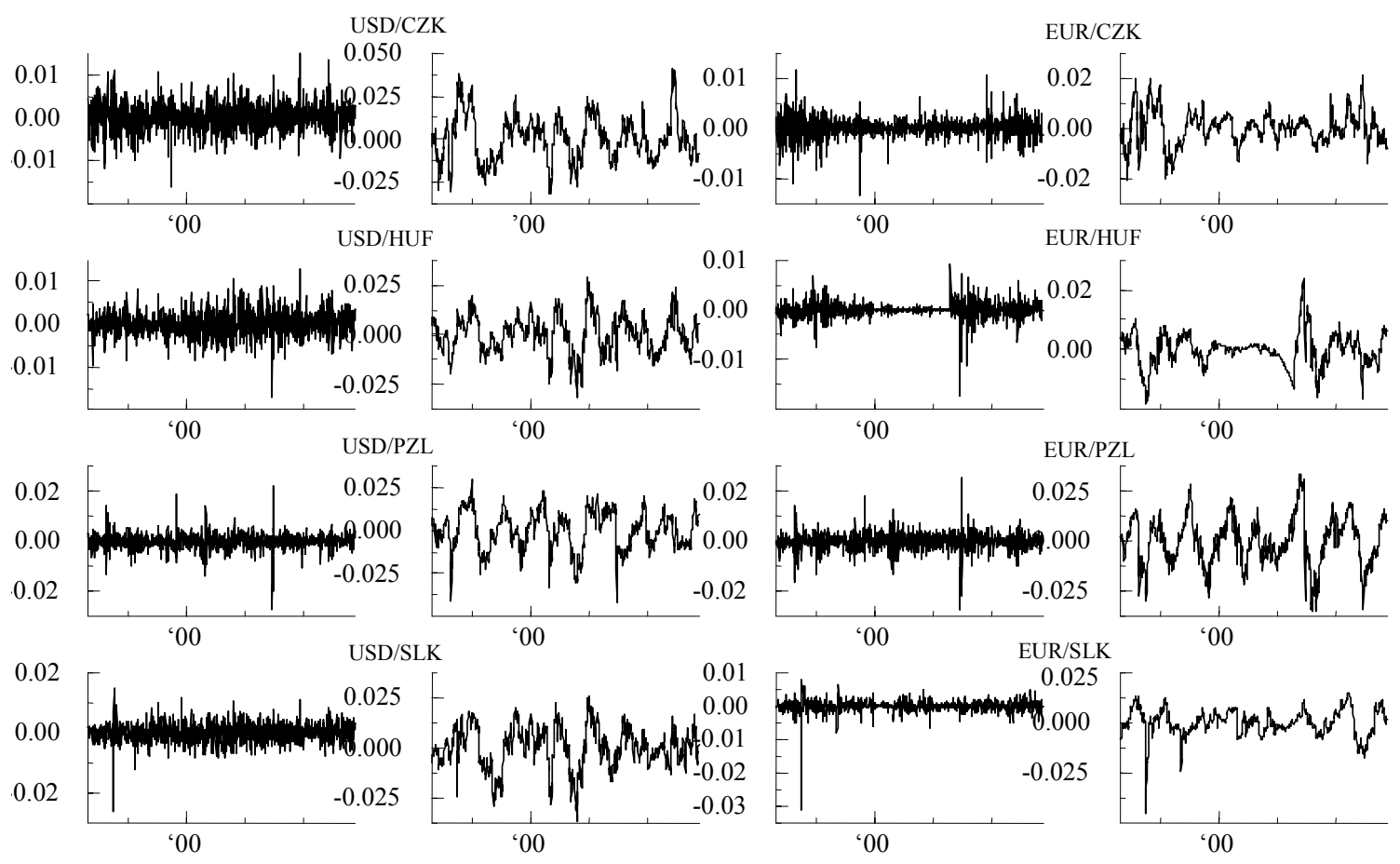

Source: Czech National Bank; author's calculations.

1/ First differences and differences from the Hodrick-Prescott filter. All data are in logs. 


\section{A. Daily data}

The results for the daily data are shown in Table 3. As is well known, the Hodrick-Prescott filter can create spurious serial correlation in detrended data (Cogley and Nason, 1995). ${ }^{14}$ Indeed, a few of the Durbin-Watson statistics are low, typically in tandem with the Pagan's error autocorrelation test. Also, the usual tests of heteroskedasticity of residuals are uncomfortably high. Therefore, we present the parameter estimates with standard errors corrected for both autocorrelation and heteroskedasticity (HACSE). The stability of estimated parameters of interest $-\alpha$ and $\beta$ - was tested in recursive regressions and the results for the euro rates are shown in Figure $5 .{ }^{15}$ The fact that these regressions explain only a limited portion of the variance of the $\Delta e_{t}$ variable (1-7 percent) is not surprising - the order flow drives daily exchange rate fluctuations, not the endogenous liquidity process.

Most point estimates of the mean reversion processes $\alpha$ and $\beta$ have the expected signs. We have found only four, statistically insignificant cases in Poland, and one in the Slovak Republic, where the proportionate mean reversion process does not hold $(\alpha>0)$, the implication being that the exchange rate tends to drift away from the trend indefinitely. With positive $\alpha$ s, however, the nonlinear process $(\beta)$ overcompensates for the linear one: when the deviation becomes "large," the exchange rate adjusts swiftly. In contrast, the additional mean reversion process fails only for the dollar exchange rate in the Slovak Republic $(\beta>0)$.

The point estimates of the proportionate mean reversion process $(\alpha)$ indicate that it would take between 7 and 60 days (up to 12 weeks) for the exchange rate to return to its trend in the absence of the nonlinear process. As expected, the speed of adjustment was the fastest in the Czech Republic and the slowest in Poland and the Slovak Republic. We also find that it is the linear process that drives the return to trend: evaluated at absolute value mean, the impact of the linear adjustment process $(n)$ was about ten times stronger than the impact of the nonlinear process $(n)^{3}$.

Accounting for nonlinear mean reversion removes some of the excess kurtosis from the data. Comparing the excess kurtosis statistics from Table 2 with the excess kurtosis statistics estimated for the residuals from Tables 3 to 6, their values are declining across currencies and periods, although the statistics itself rarely become insignificant.

\footnotetext{
${ }^{14}$ We also tested for another well-known problem of the Hodrick-Prescott filter: the filter fails at the beginning and end of the time series. Given the length of our series, exclusion of those observations does not change our results.
}

15 The structural break in Hungary's recursive estimates of $\alpha$ and $\beta$ is explained, of course, by its move away from the tight crawling peg regime toward a floating one. In line with observed link between the forint and zloty currencies, the shock was instantly transmitted to the Polish currency, but not to the Czech or Slovak currencies (Kóbor and Szekély, 2004). 
Figure 5. Recursive Estimates of $\alpha$ and $\beta$ and Their Two Standard Errors (Recursive OLS regressions of euro daily exchange rates)
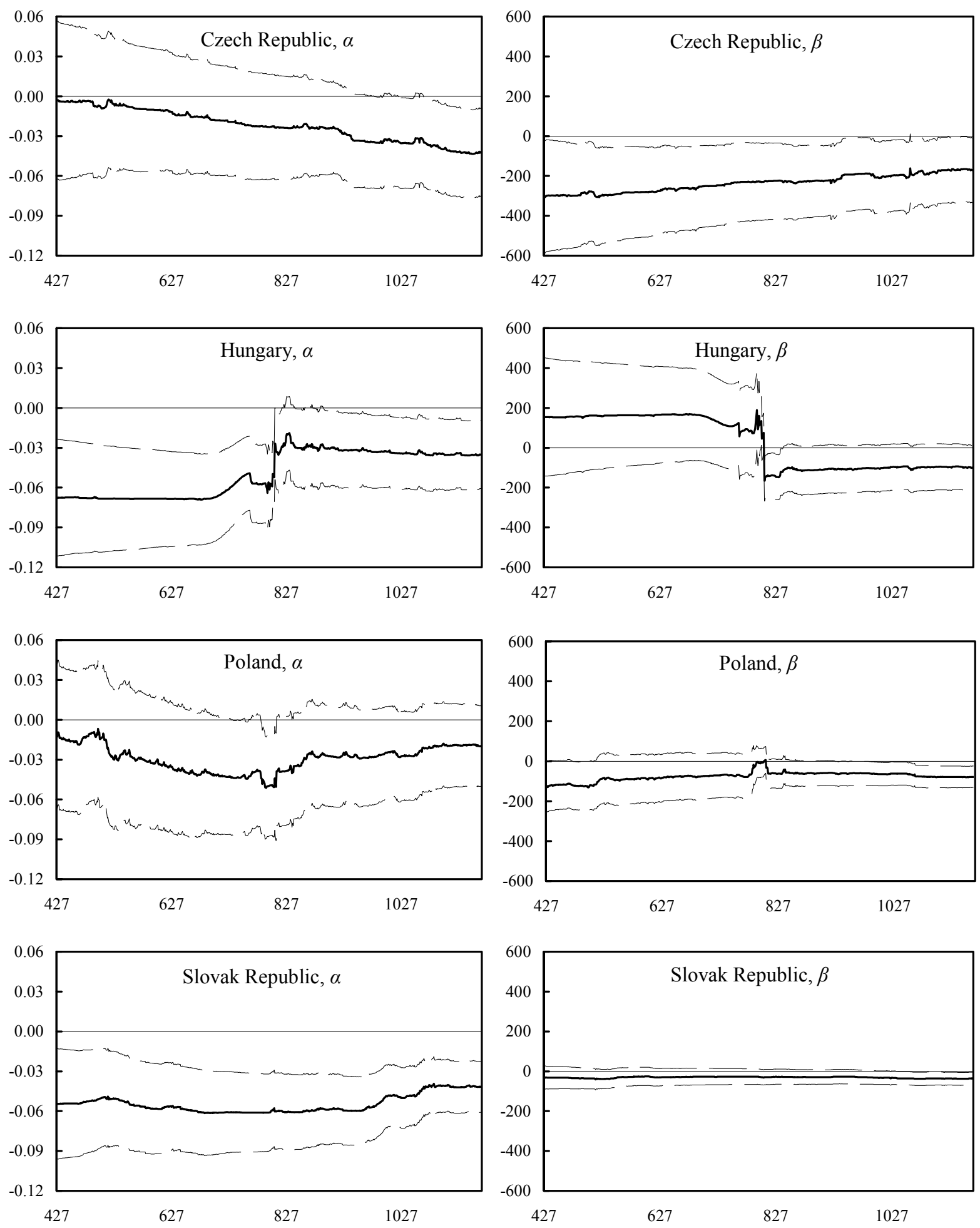

Source: Own estimates of equation (4); daily data, initialization after 400 observations. 
Table 3. Daily Data Without Lagged Dependent Variables ${ }^{1}$

\begin{tabular}{|c|c|c|c|c|c|c|c|c|}
\hline \multirow{2}{*}{$\begin{array}{l}\mathrm{C} \\
\text { Dollar }\end{array}$} & \multicolumn{2}{|c|}{ zech Republic } & \multicolumn{2}{|c|}{ Hungary } & \multicolumn{2}{|c|}{ Poland } & \multicolumn{2}{|c|}{ Slovak Republic } \\
\hline & & Euro & Dollar & Euro & Dollar Eu & ro & Dollar & Euro \\
\hline & \multicolumn{8}{|c|}{ Sample period : May 1998-December $2002(n=1141)$} \\
\hline$\alpha$ & -0.01456 & -0.02652 & $-0.03098 * *$ & $-0.02643 * *$ & 0.02559 & -0.00258 & $-0.03981 * * *$ & $-0.02996 * * *$ \\
\hline HACSE & $(0.0125)$ & $(0.0175)$ & $(0.0148)$ & $(0.0197)$ & $(0.0165)$ & $(0.0169)$ & $(0.0155)$ & $(0.0097)$ \\
\hline$\beta$ & $-32.398 *$ & $-134.83^{*}$ & -60.062 & -82.542 & $-176.82 * * *$ & $-85.676^{* *}$ & -16.872 & -10.188 \\
\hline HACSE & (16.79) & $(69.57)$ & $(45.65)$ & (161.8) & $(47.11)$ & $(43.52)$ & $(36.41)$ & $(25.51)$ \\
\hline DW & 1.93 & 2.03 & 1.93 & 2.00 & 1.89 & 2.04 & 1.89 & 1.55 \\
\hline \multirow[t]{2}{*}{$\mathrm{R}^{2}$} & 0.018 & 0.027 & 0.025 & 0.021 & 0.061 & 0.029 & 0.023 & 0.017 \\
\hline & \multicolumn{8}{|c|}{ Sample period : May 2000-December $2002(n=654)$} \\
\hline$\alpha$ & $-0.03225 * *$ & $-0.05655^{* *}$ & -0.02980 & -0.01632 & 0.02215 & 0.00375 & $-0.04837 *$ & -0.01693 \\
\hline HACSE & $(0.0163)$ & $(0.0228)$ & $(0.0198)$ & $(0.0252)$ & $(0.0223)$ & $(0.0215)$ & $(0.0202)$ & $(0.0145)$ \\
\hline$\beta$ & -9.357 & -17.680 & -61.777 & -141.46 & $-177.93 * *$ & $-84.406^{*}$ & 4.6477 & -51.647 \\
\hline HACSE & (17.33) & $(121.2)$ & $(50.54)$ & $(178.5)$ & $(73.34)$ & $(48.64)$ & $(44.49)$ & (98.50) \\
\hline DW & 1.91 & 1.98 & 1.92 & 2.00 & 1.85 & 1.99 & 1.95 & 1.76 \\
\hline \multirow[t]{2}{*}{$\mathrm{R}^{2}$} & 0.021 & 0.029 & 0.028 & 0.027 & 0.065 & 0.030 & 0.024 & 0.011 \\
\hline & \multicolumn{8}{|c|}{ Sample period : October 2001-December $2002 \quad(n=299)$} \\
\hline$\alpha$ & -0.03620 & -0.06352 & -0.03036 & -0.02350 & -0.00590 & 0.00976 & -0.06766 & 0.00838 \\
\hline HACSE & $(0.0367)$ & $(0.0409)$ & $(0.0329)$ & $(0.0231)$ & $(0.0333)$ & $(0.0225)$ & $(0.0428)$ & $(0.0194)$ \\
\hline$\beta$ & -1.0951 & -0.60180 & -144.96 & $-552.04 * *$ & $-319.79 *$ & $-138.55 * * *$ & $-631.45^{* *}$ & -178.87 \\
\hline HACSE & (29.37) & $(173.0)$ & (124.4) & $(249.9)$ & (180.4) & $(50.89)$ & (299.3) & (116.8) \\
\hline DW & 1.84 & 1.95 & 2.00 & 1.90 & 1.83 & 1.98 & 1.85 & 1.69 \\
\hline Autocor. & 2.2701 & 1.6882 & 0.3126 & 0.9763 & 1.8579 & $2.0071^{*}$ & 1.2118 & 1.3030 \\
\hline $\mathrm{R}^{2}$ & 0.019 & 0.030 & 0.032 & 0.046 & 0.035 & 0.044 & 0.071 & 0.013 \\
\hline
\end{tabular}

Source: Author's calculations.

${ }^{1}$ Estimation by ordinary least squares, robust standard errors corrected for heteroskedasticity and autocorrelation are reported in parentheses as 'HACSE'. The Durbin-Watson and error autocorrelation statistics are labeled as ' $\mathrm{DW}$ ' and 'Autocor.', respectively. The coefficient of determination is $\mathrm{R}^{2}$. The significance level at 1,5 , and 10 percent are denoted by ' $* * *$ ', '**', and '*', respectively. The parameter significance is based on robust standard errors. 
To test for the presence of random walk and to examine the robustness of our results to residual autocorrelation, we re-estimated equation 4 with 24 lagged dependent variables included in each regression (Table 4). ${ }^{16}$ Regarding the former question, we find evidence that random walk is present. On the one hand, the estimated parameters of one-period lagged dependent variables $\left(\Delta e_{t-1}\right)$ are not statistically different from zero, thus suggesting consistency with the random walk hypothesis. On the other hand, and more importantly, the estimated parameters at other lags $\left(\Delta e_{t-1-i}\right)$ are significant, although at different lag lengths for various currencies. The lagged terms are jointly significant (Annex II) and the explained variance in the model (4) rises sharply. Regarding the latter issue, residual autocorrelation became less of a problem in most regressions, although a few stubbornly correlated residuals remained (e.g., the forint/euro series).

In the augmented equation (4) both the coefficients on the proportional and nonlinear mean reversion increased in magnitude and for many of them we can reject the null hypothesis of $\alpha$ or $\beta$, or both, being equal to zero. For example, seven out of the twelve estimated $\beta$ parameters for the euro exchange rates are statistically significant and all are negative and large. Only a handful of the estimated $\alpha$ parameters are positive and none of them is significantly different from zero.

Second, the estimated $\beta$ s increase (and often become statistically significant) as we shorten the sample - with the notable exception of the Czech koruna data-perhaps as a manifestation of additional interest in those currencies from the side of international foreign exchange market makers. These findings are consistent with our observations regarding market depth. Why, then, the decline in $\beta$ s in the Czech koruna and post-2000 Hungarian forint results? We see two complementary explanations. First, the volume of Czech koruna foreign exchange trades peaked at US\$5 billion per day in late 1998/early 1999 and declined to less than one half thereafter (Figure 2). Second, we interpret declining $\beta$ s as a sign of a gradually maturing market: from the recursive estimates we see that as the absolute-value $\beta$ s decline, the absolute-value $\alpha$ s increase (Figure 6). In other words, these markets no longer require a sizable exchange rate shock to start a nonlinear, endogenous-liquidity-driven return back to the trend, because the proportional part of the mean reversion takes care of the adjustment.

\section{B. Weekly data}

We re-estimated equation 4 with the weekly data with several objectives in mind (Tables 5 and 6). First, we can investigate the time horizon of the endogenous liquidity hypothesis. For example, the speed of adjustment may be better captured in lower-frequency data. Second, we can explore the robustness of the daily data results. Third, we can compare our results directly to those of Faruqee and Redding (1999).

\footnotetext{
${ }^{16}$ It was not trivial to determine an optimal lag length. Commonly used information criteria suggested lag lengths anywhere between 12 and 38 for individual currencies and samples. The median value was 24 for daily data and 18 for weekly data.
} 
Table 4. Daily Data With Lagged Dependent Variables ${ }^{1}$

\begin{tabular}{|c|c|c|c|c|c|c|c|c|}
\hline \multirow{2}{*}{$\begin{array}{l}\text { C } \\
\text { Dollar }\end{array}$} & \multicolumn{2}{|c|}{ zech Republic } & \multicolumn{2}{|c|}{ Hungary } & \multicolumn{2}{|c|}{ Poland } & \multicolumn{2}{|c|}{ Slovak Republic } \\
\hline & & Euro & Dollar & Euro & Dollar Eu & ro & Dollar & Euro \\
\hline & \multicolumn{8}{|c|}{ Sample period : May 1998-December $2002(n=1141)$} \\
\hline$\alpha$ & $-0.02603 * *$ & $-0.04146 * *$ & $-0.04714 * * *$ & $-0.03504 *$ & 0.01136 & -0.01984 & $-0.05347 * * *$ & $-0.04170 * * *$ \\
\hline HACSE & $(0.0121)$ & $(0.0169)$ & $(0.0142)$ & $(0.0190)$ & $(0.0174)$ & $(0.0162)$ & $(0.0152)$ & $(0.0093)$ \\
\hline$\beta$ & $-44.565 * * *$ & $-172.48 * *$ & -77.618 & -99.9559 & $-191.97 * * *$ & $-77.6933 *$ & -16.402 & $-37.155 * * *$ \\
\hline HACSE & $(16.86)$ & $(78.50)$ & (47.29) & $(158.7)$ & $(57.20)$ & $(42.17)$ & $(36.34)$ & (14.44) \\
\hline DW & 2.00 & 2.00 & 2.00 & 2.00 & 1.99 & 2.00 & 2.00 & 2.01 \\
\hline Autocor. & 1.0769 & 0.8182 & 0.5858 & $3.8167 * * *$ & 0.7565 & $2.0378 * *$ & 0.1900 & $2.8731^{*}$ \\
\hline $\mathrm{R}^{2}$ & 0.047 & 0.056 & 0.052 & 0.077 & 0.081 & 0.076 & 0.053 & 0.101 \\
\hline \multicolumn{9}{|c|}{ Sample period : May 2000-December $2002(n=654)$} \\
\hline$\alpha$ & $-0.04241 * * *$ & $-0.08747 * * *$ & $-0.04340 * *$ & -0.02055 & 0.01112 & -0.00909 & $-0.06740 * * *$ & $-0.03568^{* *}$ \\
\hline HACSE & $(0.0154)$ & $(0.0241)$ & $(0.0189)$ & $(0.0241)$ & $(0.0236)$ & $(0.0199)$ & $(0.0195)$ & $(0.0154)$ \\
\hline$\beta$ & -23.125 & -52.889 & -71.2372 & -149.06 & $-188.91 *$ & $-86.951 *$ & 4.9190 & -10.313 \\
\hline HACSE & $(19.00)$ & $(124.7)$ & $(52.54)$ & $(176.2)$ & $(91.74)$ & $(48.71)$ & $(43.27)$ & $(97.73)$ \\
\hline DW & 2.00 & 2.00 & 2.00 & 2.01 & 1.99 & 1.98 & 2.00 & 2.01 \\
\hline Autocor. & 0.5460 & 0.9448 & 0.8339 & $5.6865 * * *$ & $6.0222 * * *$ & 4.1287 & 0.5122 & $2.2694 * *$ \\
\hline $\mathrm{R}^{2}$ & 0.062 & 0.068 & 0.055 & 0.012 & 0.094 & 0.109 & 0.068 & 0.079 \\
\hline \multicolumn{9}{|c|}{ Sample period : October 2001-December $2002(n=299)$} \\
\hline$\alpha$ & -0.04081 & $-0.09434 * *$ & -0.03560 & -0.02515 & -0.02948 & 0.00146 & $-0.13085 * * *$ & 0.00510 \\
\hline HACSE & $(0.0328)$ & $(0.0455)$ & $(0.0346)$ & $(0.0261)$ & $(0.0377)$ & $(0.0191)$ & $(0.0504)$ & $(0.0178)$ \\
\hline$\beta$ & -18.282 & -49.546 & -199.03 & $-526.91 * *$ & -312.92 & $-166.67 * * *$ & $-759.54 * *$ & $-190.80 *$ \\
\hline HACSE & (31.94) & $(175.7)$ & $(145.4)$ & (254.9) & $(237.3)$ & $(49.00)$ & (348.4) & (118.6) \\
\hline DW & 1.99 & 2.00 & 2.00 & 2.03 & 2.01 & 2.05 & 2.00 & 2.00 \\
\hline Autocor. & 0.4484 & 0.4273 & 0.3729 & $4.5363 * * *$ & 1.4056 & 1.9929 & 0.0672 & 0.7709 \\
\hline $\mathrm{R}^{2}$ & 0.100 & 0.100 & 0.079 & 0.127 & 0.133 & 0.176 & 0.162 & 0.096 \\
\hline
\end{tabular}

Source: Author's calculations.

${ }^{1} 24$ lagged values of the dependent variable are included in the regression, but are not reported. Estimation by ordinary least squares, robust standard errors corrected for heteroskedasticity and autocorrelation are reported in parentheses as 'HACSE'. The Durbin-Watson and error autocorrelation statistics are labeled as 'DW' and 'Autocor.', respectively. The coefficient of determination is $\mathrm{R}^{2}$. The significance level at 1,5 , and 10 percent are denoted by '***', '**', and '*', respectively. The parameter significance is based on robust standard errors. 
Table 5. Weekly Data Without Lagged Dependent Variables ${ }^{1}$

\begin{tabular}{|c|c|c|c|c|c|c|c|c|}
\hline \multirow{2}{*}{$\begin{array}{l}\text { C } \\
\text { Dollar }\end{array}$} & \multicolumn{2}{|c|}{ zech Republic } & \multicolumn{2}{|c|}{ Hungary } & \multicolumn{2}{|c|}{ Poland } & \multicolumn{2}{|c|}{ Slovak Republic } \\
\hline & & Euro & Dollar & Euro & Dollar Eu & ro & Dollar & Euro \\
\hline \multicolumn{9}{|c|}{ Sample period : May 1998-December $2002(n=216)$} \\
\hline $\begin{array}{l}\alpha \\
\text { HACSE }\end{array}$ & $\begin{array}{r}-0.03932 \\
(0.0524)\end{array}$ & $\begin{array}{r}-0.06595 \\
(0.0542)\end{array}$ & $\begin{array}{r}-0.10352 \\
(0.0630)\end{array}$ & $\begin{array}{r}-0.02543 \\
(0.0580)\end{array}$ & $\begin{array}{r}-0.08316^{*} \\
(0.0497)\end{array}$ & $\begin{array}{r}-0.02849 \\
(0.0633)\end{array}$ & $\begin{array}{r}-0.09276 \\
(0.0572)\end{array}$ & $\begin{array}{r}-0.01522 \\
(0.0341)\end{array}$ \\
\hline $\begin{array}{l}\text { DW } \\
\text { Autocor. } \\
\mathrm{R}^{2}\end{array}$ & $\begin{array}{r}1.83 \\
1.7807 * \\
0.0892\end{array}$ & $\begin{array}{r}1.69 \\
1.1746 \\
0.047\end{array}$ & $\begin{array}{r}1.88 \\
2.6335^{* *} \\
0.086\end{array}$ & $\begin{array}{r}2.03 \\
1.6027 \\
0.059\end{array}$ & $\begin{array}{r}1.86 \\
1.7495 * \\
0.051\end{array}$ & $\begin{array}{r}1.97 \\
2.5691 * * \\
0.055\end{array}$ & $\begin{array}{r}1.77 \\
3.4597 * * * \\
0.051\end{array}$ & $\begin{array}{r}1.86 \\
1.5652 \\
0.047\end{array}$ \\
\hline \multicolumn{9}{|c|}{ Sample period : May 2000-December $2002(n=135)$} \\
\hline $\begin{array}{l}\alpha \\
\text { HACSE }\end{array}$ & $\begin{array}{r}-0.04097 \\
(0.0794)\end{array}$ & $\begin{array}{r}-0.02185 \\
(0.0721)\end{array}$ & $\begin{array}{r}-0.07385 \\
(0.0823)\end{array}$ & $\begin{array}{r}-0.01678 \\
(0.0736)\end{array}$ & $\begin{array}{r}-0.09572 \\
(0.0643)\end{array}$ & $\begin{array}{r}-0.02186 \\
(0.0752)\end{array}$ & $\begin{array}{r}-0.13105^{*} \\
(0.0770)\end{array}$ & $\begin{array}{r}-0.08499 \\
(0.0607)\end{array}$ \\
\hline $\begin{array}{l}\beta \\
\text { HACSE }\end{array}$ & $\begin{array}{r}-85.983 * \\
(49.90)\end{array}$ & $\begin{array}{r}-317.37 * * \\
(161.6)\end{array}$ & $\begin{array}{r}-129.37 \\
(85.12)\end{array}$ & $\begin{array}{r}-620.72 * * \\
(311.9)\end{array}$ & $\begin{array}{r}1.8589 \\
(60.36)\end{array}$ & $\begin{array}{r}-108.75 \\
(135.5)\end{array}$ & $\begin{array}{r}-34.442 \\
(76.58)\end{array}$ & $\begin{array}{r}-102.57 \\
(248.5)\end{array}$ \\
\hline $\begin{array}{l}\mathrm{DW} \\
\text { Autocor. } \\
\mathrm{R}^{2}\end{array}$ & $\begin{array}{r}1.89 \\
1.4643 \\
0.062\end{array}$ & $\begin{array}{r}1.80 \\
0.9688 \\
0.049\end{array}$ & $\begin{array}{r}1.98 \\
1.9404 \\
0.072\end{array}$ & $\begin{array}{r}2.06 \\
2.0512 * \\
0.101\end{array}$ & $\begin{array}{r}1.84 \\
0.9668 \\
0.044\end{array}$ & $\begin{array}{r}2.00 \\
2.1794 * * \\
0.058\end{array}$ & $\begin{array}{r}1.78 \\
2.2045 \\
0.068\end{array}$ & $\begin{array}{r}1.85 \\
1.5802 \\
0.057\end{array}$ \\
\hline
\end{tabular}

Source: Author's calculations.

${ }^{1}$ Estimation by ordinary least squares, robust standard errors corrected for heteroskedasticity and autocorrelation are reported in parentheses as 'HACSE'. The Durbin-Watson and error autocorrelation statistics are labeled as 'DW' and 'Autocor.', respectively. The coefficient of determination is $\mathrm{R}^{2}$. The significance level at 1,5 , and 10 percent are denoted by '***', '**', and '*', respectively. The parameter significance is based on robust standard errors. 
Table 6. Weekly Data With Lagged Dependent Variables ${ }^{1}$

\begin{tabular}{|c|c|c|c|c|c|c|c|c|}
\hline \multirow{2}{*}{$\begin{array}{l}\text { C } \\
\text { Dollar }\end{array}$} & \multicolumn{2}{|c|}{ zech Republic } & \multicolumn{2}{|c|}{ Hungary } & \multicolumn{2}{|c|}{ Poland } & \multicolumn{2}{|c|}{ Slovak Republic } \\
\hline & & Euro & Dollar & Euro & Dollar Eu & ro & Dollar & Euro \\
\hline & \multicolumn{8}{|c|}{ Sample period : May 1998-December $2002(n=216)$} \\
\hline $\begin{array}{l}\alpha \\
\mathrm{HACSE}\end{array}$ & $\begin{array}{r}-0.14599 * * \\
(0.0462)\end{array}$ & $\begin{array}{r}-0.12525 * * \\
(0.0544)\end{array}$ & $\begin{array}{r}-0.20284 * * * \\
(0.0590)\end{array}$ & $\begin{array}{r}-0.08138 \\
(0.0566)\end{array}$ & $\begin{array}{r}-0.21714 * * \\
(0.0968)\end{array}$ & $\begin{array}{r}-0.18393 * * * \\
(0.0706)\end{array}$ & $\begin{array}{r}-0.16471 * * * \\
(0.0521)\end{array}$ & $\begin{array}{r}-0.09569 * * \\
(0.0442)\end{array}$ \\
\hline $\begin{array}{l}\beta \\
\text { HACSE }\end{array}$ & $\begin{array}{r}-57.678 \\
(44.92)\end{array}$ & $\begin{array}{l}-261.50 \\
(169.8)\end{array}$ & $\begin{array}{r}-85.643 \\
(78.69)\end{array}$ & $\begin{array}{r}-683.54 * * * \\
(262.3)\end{array}$ & $\begin{array}{l}31.272 \\
(70.09)\end{array}$ & $\begin{array}{r}-83.9694 \\
(119.9)\end{array}$ & $\begin{array}{r}-40.280 \\
(61.47)\end{array}$ & $\begin{array}{r}-204.11 * \\
(110.4)\end{array}$ \\
\hline $\begin{array}{l}\mathrm{DW} \\
\text { Autocor. } \\
\mathrm{R}^{2}\end{array}$ & $\begin{array}{r}1.99 \\
1.0444 \\
0.204\end{array}$ & $\begin{array}{r}2.00 \\
1.7225 \\
0.217\end{array}$ & $\begin{array}{r}1.97 \\
1.0720 \\
0.197\end{array}$ & $\begin{array}{r}2.06 \\
1.9527^{*} \\
0.232\end{array}$ & $\begin{array}{r}1.99 \\
0.9712 \\
0.138\end{array}$ & $\begin{array}{r}2.00 \\
2.2851^{* *} \\
0.209\end{array}$ & $\begin{array}{r}1.99 \\
0.9875 \\
0.188\end{array}$ & $\begin{array}{r}2.0 \\
7.3536^{* * *} \\
0.154\end{array}$ \\
\hline $\mathrm{R}^{2}$ & \multicolumn{8}{|c|}{ Sample period : May 2000-December $2002(n=135)$} \\
\hline $\begin{array}{l}\alpha \\
\mathrm{HACSE}\end{array}$ & $\begin{array}{r}-0.19665 * * * \\
(0.0564)\end{array}$ & $\begin{array}{r}-0.09379 \\
(0.0716)\end{array}$ & $\begin{array}{r}-0.36069 * * \\
(0.1074)\end{array}$ & $\begin{array}{r}-0.04481 \\
(0.0894)\end{array}$ & $\begin{array}{r}-0.23740 \\
(0.1533)\end{array}$ & $\begin{array}{r}-0.14425^{*} \\
(0.0795)\end{array}$ & $\begin{array}{r}-0.30068 * * * \\
(0.0894)\end{array}$ & $\begin{array}{r}-0.15068^{*} \\
(0.0795)\end{array}$ \\
\hline $\begin{array}{l}\beta \\
\mathrm{HACSE}\end{array}$ & $\begin{array}{r}-140.24 * * * \\
(50.75)\end{array}$ & $\begin{array}{r}-312.49 * \\
(186.2)\end{array}$ & $\begin{array}{r}-64.6889 \\
(84.93)\end{array}$ & $\begin{array}{r}-994.60 * * * \\
(323.5)\end{array}$ & $\begin{array}{l}54.021 \\
(89.08)\end{array}$ & $\begin{array}{r}-110.76 \\
(127.3)\end{array}$ & $\begin{array}{r}-39.103 \\
(84.71)\end{array}$ & $\begin{array}{r}-382.82 \\
(247.7)\end{array}$ \\
\hline DW & 1.99 & 2.01 & 1.96 & 2.11 & 1.89 & 1.96 & 1.97 & 2.01 \\
\hline Autocor. & 1.1319 & $4.0984 * * *$ & 1.0813 & $4.3844 * * *$ & $2.8731 * * *$ & 1.3880 & 1.1936 & 1.5713 \\
\hline $\mathrm{R}^{2}$ & 0.262 & 0.190 & 0.225 & 0.302 & 0.135 & 0.284 & 0.207 & 0.242 \\
\hline
\end{tabular}

Source: Author's calculations.

${ }^{1} 18$ lagged values of the dependent variable are included in the regression, but are not reported. Estimation by ordinary least squares, robust standard errors corrected for heteroskedasticity and autocorrelation are reported in parentheses as 'HACSE'. The Durbin-Watson and error autocorrelation statistics are labeled as 'DW' and 'Autocor.', respectively. The coefficient of determination is $\mathrm{R}^{2}$. The significance level at 1,5 , and 10 percent are denoted by '***', '**', and '*', respectively. The parameter significance is based on robust standard errors. 
We find little difference in the overall explanatory power of the model with weekly as compared to daily data. It appears that the nonlinear error correction mechanism is at play in the same countries as with the daily data and there is not much information one can use for deciding between the dailyand weekly-data results. As expected, the weekly data are less choppy than the daily data and, as a result, the adjusted $\mathrm{R}^{2}$ is somewhat higher, explaining between 5 and 10 percent of the variance of the dependent variable

Similar to the daily-data results, we have some reservations with respect to the serially correlated residuals in the model without lagged dependent variables (Table 5) and, hence, we focus primarily on the full-blown estimates with 18 lagged dependent variables (Table 6). All $\alpha$ parameters have the expected negative signs and only four out of the 16 point estimates in the two sample periods are not statistically different from zero (all either in the shortest subsample or in the U.S. dollar data). The estimates indicate that it would take between 2 and 15 weeks for the exchange rate to return to its long-term value in the absence of the nonlinear process. The size of the estimated $\beta$ parameters and their statistical significance is comparable to the daily data models as are the findings with respect to the random walk hypothesis. The endogenous liquidity hypothesis seems to be validated especially in the full sample of the Czech koruna and shorter samples of the Hungarian forint

For comparison, the median Faruqee-Redding estimate of $\alpha$ for weekly data $(-0.18)$ in the G-7 countries suggests a faster linear mean-reversion process than our median estimate of $\alpha(-0.15)$. Our results imply, however, a more forceful nonlinear adjustment: our estimates of $\beta$ (median of -85) are a multiple of that for G-7 (median of -15). This is a fairly intuitive result - it takes a larger departure from the trend in transition economies, as compared to the G-7 countries, to attract endogenous liquidity to the market. Nevertheless, given the weight of the linear adjustment process as compared to the nonlinear one, the overall speed of adjustment remains slower for the Visegrád Four countries as compared to the $\mathrm{G}-7$ countries.

\section{Volatility of Exchange Rate and Central Bank Interventions}

One important question to be examined in interpreting the results is whether they may, in part, reflect central bank intervention and regulatory pressures to curb short-term exchange rate volatility. ${ }^{17}$ We find a limited role of interventions for volatility smoothing, for the following reasons.

First, most interventions in the Visegrád Four countries were against the domestic currency, as the authorities tried to limit real appreciation with little interest in day-to-day nominal volatility (Holub, 2004). ${ }^{18}$ Moreover, quantitative interventions were too small and infrequent to have a

\footnotetext{
${ }^{17}$ The literature yields little support to the hypothesis that interventions can calm financial markets or reverse market expectations, although this hypothesis is often seen as the primary justification for central bank interventions. See Stix (2001) for a review.

${ }^{18}$ Interventions turned out to be quite costly for central banks as domestic interest rates declined sharply in the late 1990s. Holub (2004) estimated 2001-02 average annual sterilization cost thereof in the Czech National Bank to be equivalent to 1.5 percent of GDP.
} 
marked impact on exchange rate volatility. For example, the CNB monthly average of interventions was less than US\$100 million during 2000-2002 or equivalent to about 0.2 percent of the turnover on the koruna market and those averages were even smaller for Hungary and the Slovak Republic. Of course, the signaling impact of quantitative interventions is hard to gauge as it depends on the market structure (Bofinger and Wollmershaeuser, 2001, and Kim, 2003) or the prevailing volatility regime (Beine, Laurent, and Lecourt, 2003). Even less can be said about regulatory pressures, although it is known that some foreign exchange market participants may "restrain" themselves voluntarily if they are worried that the central bank might "punish" them.

Second, we found no quantitative evidence that interventions may have curbed exchange rate volatility. Regressing within-the-month volatility of exchange rates on monthly interventions for the period of January 1999-December 2002, and controlling for contagion and trend-related movements in the exchange rate, we found that big-intervention months were associated in statistically significant manner with bigger volatility and vice versa in the Czech Republic, while the same exercise for Hungary and the Slovak Republic yielded statistically insignificant results. Hence, if the Czech, Hungarian, and Slovak central banks indeed tried to limit daily volatility of their currencies through quantitative interventions, these efforts do not show in our data.

\section{Policy Implications}

Our results have some attractive policy implications. First, the results suggest that early liberalization of the foreign exchange market and financial-account transactions may pay off in terms of market liquidity and, hence, faster adjustment of the exchange rate. This would increase the viability of a floating regime, as well as making it more difficult to maintain a pegged regime. However, early liberalization is a necessary condition, not a sufficient one. For example, although the Slovak koruna was floated soon after the Czech koruna, the Slovak market remained thin and the turnover on the foreign exchange market grew slowly. Similarly, the floating of the Hungarian forint in 2001 and the rapid growth in turnover appear to be associated with fastgrowing liquidity. Moreover, the results for the Czech koruna suggest that a deep, maturing market is likely to be characterized by a gradually increasing weight of the linear adjustment processes. The speed of proportional adjustment of the Czech koruna and, more recently, the Hungarian forint is gradually becoming comparable to that of the G-7 countries.

Second, central banks need not be overly concerned with short-run volatility of their national exchange rates, given the self-correcting tendencies. This seems to be the practice of Visegrád Four central banks anyway, for they "lean against the wind" of real appreciation as compared to smoothing out short-term fluctuations as suggested by the conventional view of foreign exchange interventions. We even found evidence that CNB interventions were associated with increased exchange rate volatility.

Third, the endogenous liquidity effects are comparable empirically to the autoregressive processes of the random walk. Endogenous liquidity does not imply that the volatility of the nominal exchange rate is lower in a liquid market or that the level thereof is closer to its fundamental-based exchange rate, it only implies that the self-correcting mechanism is fast. The endogenous liquidity hypothesis seems to hold especially well in all samples of the Czech koruna and shorter samples of the Hungarian forint. 
Finally, we conjecture that nontransparent exchange rate arrangements and shallow markets in Poland and the Slovak Republic may have induced an irregular behavior of the exchange rate. For example, the Polish zloty is an outlier - in terms of similar volatility of both the dollar and euro exchange rates, positive signs of the estimated proportional mean reversion process $(\alpha)$, and comparatively large $\beta \mathrm{s}$ in the daily regressions. The results suggest that the zloty exchange rate adjusts only if the departure from the trend is large and that in the case of smaller deviations the rate tends to drift further from the trend, because a limited amount of endogenous liquidity is attracted into the market. We find similar results for the euro rate of the Slovak koruna in the 2001-2002 period.

\section{Concluding Remarks}

Utilizing the empirical model of Faruqee and Redding (1999), we test endogenous liquidity provision in four Central European foreign exchange markets. In this model, stabilizing flows of liquidity are attracted to a market with a seemingly temporary shock to the exchange rate, reacting disproportionately fast to sizeable deviations from the longer-term exchange rate path. The testable equation contains a univariate error-correction mechanism that captures both the linear and nonlinear parts of the mean reversion process. This "endogenous liquidity" hypothesis suggests also a second channel through which opening financial markets militates in favor of exchange rate flexibility: it increases the viability of a floating regime, as well as making it more difficult to maintain a peg.

The empirical part of the paper validated the theoretical priors and found that the depth of the market may have implications for the speed of adjustment of the error-correction mechanism. We found the strongest support for the endogenous liquidity hypothesis in the Czech koruna market and, more recently, also in the Hungarian forint market. Quantitatively, the results are comparable to those of Faruqee and Redding for G-7 countries. The model was tested using weekly and daily exchange rate data for the U.S. dollar and euro against four Central European currencies for the 1998-2002 sample period, the Czech and Slovak korunas, Hungarian forint, and Polish zloty. In addition, we found some evidence that central bank interventions in the foreign exchange market may have fueled exchange rate volatility, presumably as a result of the "leaning against the wind" approach to interventions.

Liquid currencies, that is, those with a sufficient number of market makers and deep order books, tend to have shorter deviations from the trend exchange rate. The results seem to suggest a connection between the early liberalization of the foreign-exchange market and financial-account transactions in the Czech Republic and the resulting, faster-than-average adjustment of the Czech koruna to short-term deviations from the trend. A similar link between market deepening and the speed of adjustment of the exchange rate is observable in the post-2000 Hungarian data. As far as the out-of-sample forecasting accuracy is concerned, the endogenous-liquidity model performs comparably to the random walk model. We found limited clues, however, as to what is the appropriate frequency for testing the endogenous liquidity hypothesis - we have to wait for longer time series under consistent exchange rate arrangements. Further empirical extensions of the model may want to consider the impact of central bank interventions on the speed of exchange rate adjustment. 


\section{The Faruqee-Redding Model of Endogenous Liquidity}

This section recapitulates the three-period model presented in Faruqee and Redding (1999) and (2001). In this model non-informational, noise traders' demand for liquidity, $\eta_{t} \sim\left(0, \sigma_{\eta}^{2}\right)$, which is positively serially correlated, is met by risk-averse market makers, $M_{t}$, who are willing to speculate in order to collect an end-period expected profit. Those informational traders choose the optimal asset holding given a utility function with constant risk aversion, $\gamma$, in terminal wealth:

$$
U_{t}\left(W_{0}, H_{t}\right)=\left[W_{0}+H_{t}\left(E_{t} P_{3}-P_{t}\right)\right]-\frac{\gamma}{2} H_{t}^{2} \sigma_{t}^{2},
$$

where the first right-hand side term measures the end-period expected wealth and the second denotes the penalty on the variance of wealth. In equilibrium the noise-trader demand must equal the market-maker demand:

$$
P_{t}=E_{t} P_{3}+\frac{\eta \gamma \sigma_{t}^{2}}{M_{t}}
$$

Market makers are attracted to markets where noise trading is significant, resulting in additional entry in period 2, providing an expected excess utility of the optimal holdings over the initial wealth $W_{0}$ :

$$
U_{2}-W_{0}=\frac{\left(E_{2} P_{3}-P_{2}\right)^{2}}{2 \gamma \sigma^{2}} .
$$

Using the all-trader equilibrium (2) and inserting into (3) yields:

$$
U_{2}-W_{0}=\frac{\eta^{2} \gamma \sigma_{2}^{2}}{2 M_{2}^{2}} .
$$

Assuming the reservation utility of the marginal market maker to be linear in the number of market makers, $R\left(M_{2}\right)=\phi M_{2}$, period 2 entry will be conditional on surplus from market making (4) exceeding the reservation cost. Hence, the equilibrium number of market makers will be:

$$
M_{2}=\sqrt[3]{\frac{\eta^{2} \gamma \sigma_{2}^{2}}{2 \phi}}
$$

and, consequently, the period 2 price:

$$
P_{2}=E_{2} P_{3}+\sqrt[3]{2 \phi \eta \gamma^{2}\left(\sigma_{2}^{2}\right)^{2}}
$$

Non-informational traders have transitory effect on the exchange rate $P_{t}$, while market makers bring it back to fundamental value. The speed of adjustment - an error correction metric - varies between 0 (no second-period adjustment) and 1 (full second-period adjustment):

$$
\omega=1-\frac{\left|E_{2}\left(P_{2}-P_{3}\right)\right|}{\left|E_{1}\left(P_{1}-P_{3}\right)\right|} .
$$


Fixing the number of second-period market makers, that is, assuming no endogenous liquidity provision, the error correction mechanism is independent of transitory demand $(\eta)$, $\omega=1-\sigma_{2}^{2} M_{1} / \sigma_{1}^{2} M_{2}$. Using equation (2) to incorporate the effect of endogenous liquidity, the metric increases in the absolute value of transitory demand $(\eta)$ :

$$
\omega=1-\sqrt[3]{\frac{2 \phi}{\gamma \eta^{2} \sigma_{2}^{2}}} \frac{\sigma_{2}^{2}}{\sigma_{1}^{2}} M_{1} .
$$

Intuitively, this result indicates that a large non-informational, first-period trading encourages more forceful return toward fundamental value in the next period, both on an absolute and proportional basis $\partial \omega / \partial \eta>0$. 


\section{The Meese-Rogoff "Race"}

Comparing out-of-sample forecasting accuracy, or the so-called Meese and Rogoff (1983) "race," of the various empirical models used in this paper, we find that the pure random walk model (column 1) performs quite similarly to the Faruqee-Redding model without lagged variables (column 2). More specifically, random-walk model's root mean square errors (RMSE) are marginally lower than those of the endogenous liquidity model for Czech koruna and zloty, but marginally higher for the forint and the Slovak koruna. Predictably, the Faruqee-Redding model with lagged variables (column 3) shows lower RMSE than either of the two preceding models for most currencies and forecasting periods.

Root Mean Square Forecast Error in Out-of-Sample Estimates of Equation (4) (RMSE x 100)

\begin{tabular}{|c|c|c|c|c|}
\hline & $\begin{array}{l}\text { Period of } \\
\text { forecast }\end{array}$ & $\begin{array}{l}\text { Random walk } \\
\text { model } \\
\text { (1) }\end{array}$ & $\begin{array}{l}\text { Model of } \\
\text { endogenous } \\
\text { liquidity } \\
\text { (2) }\end{array}$ & $\begin{array}{l}\text { Model of } \\
\text { endogenous } \\
\text { liquidity with } \\
\text { random walk } \\
\text { (3) }\end{array}$ \\
\hline \multirow{3}{*}{ CZK/EUR } & 1 week & 0.217 & 0.226 & 0.204 \\
\hline & 2 weeks & 0.167 & 0.175 & 0.157 \\
\hline & 1 month & 0.172 & 0.173 & 0.163 \\
\hline \multicolumn{2}{|c|}{ Exclusion restriction ${ }^{1} \mathrm{NA}$} & & NA & 1.544 \\
\hline \multirow{3}{*}{ HUF/EUR } & 1 week & 0.060 & 0.051 & 0.054 \\
\hline & 2 weeks & 0.073 & 0.064 & 0.074 \\
\hline & 1 month & 0.089 & 0.087 & 0.093 \\
\hline \multicolumn{2}{|c|}{ Exclusion restriction ${ }^{1} \mathrm{NA}$} & & NA & 2.808 \\
\hline \multirow{3}{*}{ PZL/EUR } & 1 week & 0.176 & 0.188 & 0.174 \\
\hline & 2 weeks & 0.181 & 0.193 & 0.184 \\
\hline & 1 month & 0.154 & 0.164 & 0.154 \\
\hline \multicolumn{2}{|c|}{ Exclusion restriction ${ }^{1} \mathrm{NA}$} & & NA & 2.192 \\
\hline \multirow{3}{*}{ SLK/EUR } & 1 week & 0.254 & 0.236 & 0.237 \\
\hline & 2 weeks & 0.258 & 0.253 & 0.249 \\
\hline & 1 month & 0.212 & 0.209 & 0.205 \\
\hline \multicolumn{2}{|c|}{ Exclusion restriction ${ }^{1} \mathrm{NA}$} & & NA & 4.300 \\
\hline
\end{tabular}

Source: Author's calculations; daily data. The estimated RMSE are derived from the following equations: $\Delta e_{t}=\sum_{1}^{24} \delta_{i} \Delta e_{t-i}+\varepsilon_{t}, \Delta e_{t}=\alpha n_{t-1}+\beta\left(n_{t-1}\right)^{3}+\varepsilon_{t}$, and $\Delta e_{t}=\alpha n_{t-1}+\beta\left(n_{t-1}\right)^{3}+\sum_{1}^{24} \delta_{i} \Delta e_{t-i}+\varepsilon_{t}$, respectively.

${ }^{1}$ An $F$-test of joint exclusion of lagged variables, distributed as $F(24,1114)$. 


\section{References}

Bacchetta, Phillippe, and Eric van Wincoop, 2003, "Can Information Heterogeneity Explain the Exchange Rate Determination Puzzle?” CEPR Discussion Paper No. 3808 (London: Centre for Economic Policy Research).

Beine, Michel, Sébastien Laurent, and Christelle Lecourt, 2003, "Official Central Bank Interventions and Exchange Rate Volatility: Evidence from a Regime-Switching Analysis," European Economic Review, Vol. 47 (October), pp. 891-911.

Bofinger, Peter, and Wollmershaeuser, Timo, 2001, "Managed Floating: Understanding the New International Monetary Order," CEPR Discussion Paper, No. 3064 (London: Centre for Economic Policy Research).

Cogley, Timothy, and James M. Nason, 1995, "Effects of the Hodrick-Prescott Filter on Trend and Difference Stationary Time Series: Implications for Business Cycle Research,” Journal of Economic Dynamics and Control, Vol. 19 (January-February), pp. 253-278.

Darvas, Zsolt, and György Szapáry, 2000, "Financial Contagion in Five Small Open Economies: Does the Exchange Rate Regime Really Matter?” International Finance, Vol. 3, No. 1, pp. 25-51.

Derviz, Alexis, 2003, "Components of the Czech Koruna Risk Premium in a Multiple-Dealer FX Market," Czech National Bank Working Paper, No.4 (Prague: Czech National Bank). Available via the Internet: http://www.cnb.cz/en/pdf/wp4-2003.pdf.

Devereux, Michael B., and Philip R. Lane, 2003, "Understanding Bilateral Exchange Rate Volatility,” Journal of International Economics, Vol. 60 (May), pp. 109-132.

Eichengreen, Barry, 2001, “Capital Account Liberalization: What Do Cross-Country Studies Tell Us?” The World Bank Economic Review, Vol. 15, No. 3, pp. 341-365.

Evans, Martin D. D., and Richard K. Lyons, 2002, "Order Flow and Exchange Rate Dynamics," Journal of Political Economy, Vol. 110 (February), pp. 170-180.

Faruqee, Hamid, and Lee Redding, 1999, "Endogenous Liquidity Providers and Exchange Rate Dynamics," Canadian Journal of Economics, Vol. 32 (August), pp. 976-994. , 2001, “Asset Markets and Endogenous Liquidity," Scottish Journal of Political Economy, Vol. 48 (May), pp. 196-209.

Ghosh, Atish R., Anne-Marie Gulde, and Holger C. Wolf, 2003, Exchange Rate Regimes: Choices and Consequences, MIT Press (Boston: Massachusetts).

Granger, Clive W.J., and Pierre L. Siklos, 1997, "Regime-Sensitive Cointegration with an Application to Interest-Rate Parity," Macroeconomic Dynamics, Vol. 1, No. 3, pp. 640-657. 
Holub, Tomáš, 2004, "Foreign Exchange Interventions Under Inflation Targeting: The Czech Experience," Czech National Bank Internal Research and Policy Note, No.1/2004 (Prague: Czech National Bank). Available via the Internet: http://www.cnb.cz/en/pdf/IRPN_1_2004.pdf.

Johansen, Soren, and Katerina Juselius, 1990, "Maximum Likelihood Estimation and Inference on Cointegration, with Applications to the Demand for Money," Oxford Bulletin of Economics and Statistics, Vol. 52 (May), pp. 169-209.

Kim, Soyoung, 2003, "Monetary Policy, Foreign Exchange Intervention, and the Exchange Rate in a Unifying Framework,” Journal of International Economics, Vol. 60 (August), pp. 355-386.

Kóbor, Ádám, and István P. Székely, 2004, “Foreign Exchange Market Volatility in EU Accession Countries in the Run-Up to Euro Adoption: Weathering Uncharted Waters," IMF Working Paper 04/16 (Washington: International Monetary Fund). Available via the Internet: http://www.imf.org/external/pubs/ft/wp/2004/wp0416.pdf.

Meese, Richard A., and Kenneth Rogoff, 1983, "Empirical Exchange Rate Models of the Seventies: Do They Fit Out of Sample?” Journal of International Economics, Vol. 14 (February), pp. 3-24.

Merton, Robert C., 1987, “A Simple Model of Capital Market Equilibrium with Incomplete Information," Journal of Finance, Vol. 42 (July), pp. 483-511.

Panthaki, Jehan, 2004, "Can Volatility in the Zloty/Euro Exchange Rate Be Explained by the U.S. Dollar/Euro Cross Rate?” unpublished note, International Monetary Fund (Washington: International Monetary Fund).

Reinhart, Carmen M., and Kenneth S. Rogoff, 2002, “The Modern History of Exchange Rate Arrangements: A Reinterpretation,” NBER Working Paper No. 8963 (Cambridge, Mass.: National Bureau of Economic Research). Available via the Internet: http://papers.nber.org/papers/w8963.pdf.

Sarno, Lucio, 2003, "Nonlinear Exchange Rate Models: A Selective Overview," IMF Working Paper 03/111 (Washington: International Monetary Fund). Available via the Internet: http://www.imf.org/external/pubs/cat/longres.cfm?sk=16541.0.

Schardax, Franz, 2002, "Exchange Rates and Long-Term Interest Rates in Central Europe: How Do Monetary and Fiscal Policy Affect Them?” Focus on Transition, Vol. 7, No. 2, pp. 58-71.

Stix, Helmut, 2001, "Does Central Bank Intervention Influence the Probability of a Speculative Attack? Evidence from the EMS," OeNB Working Paper 80, (Wien: Oesterreichische Nationalbank). Available via the Internet: http://www2.oenb.at/workpaper/wp80.pdf.

Wickham, Peter, 2002, “Do 'Flexible' Exchange Rates of Developing Countries Behave Like the Floating Exchange Rates of Industrialized Countries?” IMF Working Paper 02/82 (Washington: International Monetary Fund). Available via the Internet: http://www.imf.org/external/pubs/cat/longres.cfm?sk=15636.0 